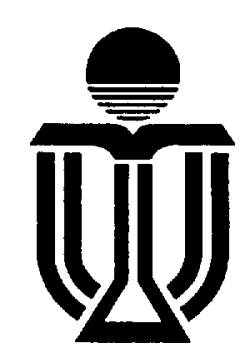

Division of Social Science

The Hong Kong University of Science and Technology

Working Papers in the Social Sciences, No. 46

\title{
China's Monetary Reform: The Counterrevolution from the Countryside
}

by

Carsten A. Holz

Division of Social Science Hong Kong University of Science and Technology Clear Water Bay Kowloon, Hong Kong

28 April 1999 


\title{
China's Monetary Reform: \\ The Counterrevolution from the Countryside
}

\author{
Carsten A. Holz \\ Social Science Division \\ Hong Kong University of Science \& Technology \\ Clear Water Bay \\ Kowloon \\ Hong Kong \\ Tel. (852) 2358-2422 \\ Fax (852) 2335-0014 (Attn. C. Holz) \\ E-mail:socholz@usthk.ust.hk
}

27 April, 1999

Financial support through a Direct Allocation Grant of the Hong Kong University of Science and Technology is gratefully acknowledged. I would like to thank David Zweig, Jen-Chi Cheng and the participants of the session on Economic Reforms in China at the Allied Social Science Association meetings in January 1999 for their comments. 


\begin{abstract}
In the past decade China's financial sector has developed rapidly. What is often ignored is the rise in financial institutions operating outside the formal financial sector. This paper focuses on the rural cooperative funds attached to lower-level tier governments and Party Committees. Their rise is explained in the context of a centrallocal as well as an intra-central conflict. While rural cooperative funds may pose a threat to local financial as well as nationwide macroeconomic stability, rigorously supervised funds with a clearly defined lending purpose can fulfill an important niche function. Although rural cooperative funds are government-controlled institutions, their hard budget constraint, a little regulated business environment and implicit local government deposit guarantees lead $t o$ an improvement in rural financial intermediation that neither the formal financial sector nor a private financial sector could achieve.
\end{abstract}

Journal of Economic Literature classification: G2, O16 and 17, P34

Keywords (all on China): rural finance, informal finance, financial intermediation, central-local relations, intra-central policy coordination 


\section{Introduction}

China's rural economy has little access to formal financial sector funding. While township- and village-run enterprises accounted for $14.95 \%$ of China's GDP in 1996 , only $3.57 \%$ of all loans of the formal banking system went to these enterprises. Individual-owned and joint enterprises fare little better. ${ }^{1}$ But this does not necessarily imply a lack of external funds. Up to $50 \%$ of all enterprise borrowing throughout China may in recent years have been provided by sources outside the formal financial sector (Qin 1993).

In the countryside these sources include, among others, loans between individuals (minjian daikuan), loans extended by private banks and government departments, bank loans lent on by state-owned enterprises, as well as off-balance sheet financing from the formal financial sector. ${ }^{2}$ One of the most significant developments since 1994 has been the rapid spread of various forms of "rural cooperative funds" (nongcun hezuo jijinhui) in many locations across the country. While rural cooperative funds (RCFs) were originally set up in the late 1980s to manage the financial property of the disbanded communes and production brigades,

1 See ZGTJNJ 1997, 42 and 622, and ZGXZQYNJ 1997, 121. The formal banking system includes the four state commercial banks and all other nationwide and regional commercial banks, savings deposit agencies of postal offices, housing saving banks, urban and rural credit cooperatives, urban cooperative banks, financial trust and investment agencies, and finance companies. Township-and village-run enterprises together with joint enterprises (owned jointly by several individuals) and individualowned enterprises, all in the countryside, constitute "township and village enterprises" (TVEs)

2 For more details sce, for example, Zhu and Hu (1997), Jiang (1996), and Xu and Deng (1994). Hu and Zhang (1998) describe the recent reforms in the rural financial sector. 
the RCFs of the early and mid-1990s had their eyes set on much grander development objectives.

The proliferation of RCFs has led to a spade of local survey reports in Chinese newspapers and journals in the mid-1990s. ${ }^{3}$ The failure of three RCFs in Lanxi Municipality, Zhejiang Province, triggered a severe and much publicized criticism by the State Council (Renmin ribao 25 Nov. 1996). But neither the rise and evolution of the RCFs nor the significance of this development are well understood. Why did RCFs evolve and grow as rapidly as they did? With RCFs turning into a prominent financial force in many rural areas, what constraints do they face, and why were these constraints not adequate to prevent RCFs from taking over large swathes of rural finance?

The rise of the RCFs in many localities is in the following explained in the context of a central-local conflict as well as an intra-central conflict. Local economic growth was stunted by a lack of financing when the formal financial sector was re-centralized and fiscal resources dried up in the early 1990s. New sources of financing were created locally through the RCFs established under the protective shield of the Agricultural Ministry despite vocal central bank opposition.

The continued existence if not growth of RCFs has a number of economic implications. RCFs prevent the outflow of rural deposits into urban areas and furthermore serve primarily that part of the local economy neglected by the formal financial sector. On the other hand, their internal structure is weak with few control mechanisms while

The English language literature has so far taken little notice of the RCFs. Park, Brandt, and Giles (1997) in their survey of rural financial institutions note the existence of rural cooperative funds and their extent in the surveyed localities as part of the rural financial system. Tsai (1999) investigates the relationship between local govemment attitudes towards the private economy and the development of different informal financial institutions. 
external checks are almost completely absent; this raises questions about their financial health. RCFs furthermore have an impact on the liquidity as well as the profitability (and therefore solvency) of the formal financial sector, and thus influence central bank policies and endanger net worth of the state-owned banks.

Although RCFs resemble the formal financial sector in that they are government-controlled institutions. they also lead a monetary counterrevolution from the countryside in that they pose a major challenge to the rural formal financial sector through their marketoriented banking practices. Operating in a little regulated business environment with a hard budget constraint-while enjoying an implicit local government deposit guarantee- results in a degree of rural financial intermediation that neither the formal financial sector nor a private financial sector could achieve.

The paper draws on nationwide as well as provincial and subprovincial tier evidence. Findings from interviews in several counties of the three regions of China are supplemented by official statistics, case studies in the Chinese literature, and relevant government documents. ${ }^{4}$ On the provincial and sub-provincial tier disproportionate attention is given to Shaanxi Province, a trial province for the establishment of farmer associations from 1994 to $1997 .^{5}$

$4 \quad$ Interviews were conducted throughout 1997 and 1998 in several counties of Shaanxi Province (Western region), Hebei and Henan Province (central region), Jiangsu Province (coastal region) as well as in Beijing.

Central government documents are available from a number of law collections. Local government documents are frequently on display in the RCFs in an attempt to create an image of respectability, at times in competition with other local RCFs.

5 See SXNJ 1995, 122. 


\section{Characteristics and Extent of Rural Cooperative Funds}

The origins of the RCFs date back to the mid-1980s when local governments searched for ways to manage communal funds accumulated in the by then abandoned communes, production brigades, and production teams. Most of these RCFs were closed cooperative funds run on township and village tier, and their task was limited to administering communal funds. The RCFs consisted of no more than a set of accounts; all business was conducted through the formal banking system. ${ }^{6}$

It was only after Deng Xiaoping's tour through South China in spring 1992 that the character of the cooperative funds began to change. RCFs in their modern form as quasi-banks began to grow rapidly in Sichuan Province as early as 1994. 'Today, RCFs come in a number of variations. RCFs are either

* defined by the category of borrowers (such as township and village enterprises, or farmers), or

* united by a particular depositor background (such as membership of a trade union or a supply and marketing cooperative), or

* set up for the sole benefit of a singular government or Party unit (such as a local finance department).

Most of these cooperative funds carry the qualification "rural" in their name even if they are located in urban districts. "RCF" in the following

\footnotetext{
6 By end-1988 Shaanxi Province had approximately 370 such cooperative funds with total liabilities of $40 \mathrm{~m}$ yuan, compared to total deposits at state banks and rural credit cooperatives of $21,033 \mathrm{~m}$ yuan. (Shaanxi ribao 89/5/13 and SXTJNJ 1990, 407 and 409)
} 
is used as a generic term to cover cooperative funds with the characteristics outlined in this section. ${ }^{7}$

\section{Characteristics of rural cooperative funds}

RCFs share a number of basic characteristics. (For case studies see the Appendix.) RCFs are not financial institutions (jinrong jigou) but mutual aid organizations (huzhuzu) without profit objective. Since RCFs are not financial institutions, they are not allowed to attract deposits (cunkuan), give loans (daikuan), and to pay interest (lilu). Instead, they offer shares (rugu) and borrowing (jiekuan), and pay a user fee on the shares (zhanyongfei). In practice, these differences are semantic only.

RCFs are run and regulated by the founding government or Party department on county tier, and registered with the county agricultural department. In the early phases the government department typically provides seed capital which later is withdrawn. County-tier governments and Party organs organize mass meetings to promote the RCF and assign depositing tasks to their departments and lower-level tier institutions. RCFs are owned by shareholders comprising collective-owned enterprises, government units and individuals. 'The particular ownership

7 All the funds mentioned are "open" cooperative funds in that they are open to the public. Closed funds, on the other hand, have a limited number of clearly identified members; their existence is frequently not known to the public. One example are cooperative funds run by the "financial guidance station" (caiwu zhidao zhan) of the Rural Work Department (nongcun gongzuo bu of the Party. In many localities these funds are not open to the public and go by the name "internal fund circulation work" (neibu zijin rongtong yewil). Another example are RCFs run by the administration of economic development zones. An altogether different category of closed funds are the traditional neighborhood funds (hehui) with their various accumulation and distribution principles (see, for example, Jiang 1996, Chapter 2). This article in the following focuses on open funds. 
configuration varies from province to province (see Table 1) but individuals tend to hold between a quarter to three quarters of all shares. Although shareholders have the authority to at an annual shareholder meeting determine the leadership of the RCF, in practice the RCF is run directly out of the government or Party department to which it is attached. Managers are frequently former, if not current, government or Party employees, while the Board of Directors and the Supervisory Committee (if existent) comprise concurrent government and Party staff. ${ }^{8}$

RCFs offer a choice of at least two types of shares, on the one hand a share which is equal to deposits in all but name and freely redeemable, and on the other hand a "basic" share which supposedly cannot be withdrawn. The distinction carries implications for voting rights at the shareholder meeting and for the return on the share; the deposit-type share carries no voting right and only pays interest (and/or a fixed "dividend"), while the basic share comes with voting rights and pays interest and a profit-dependent dividend. ${ }^{9}$ The return on shares is determined by the superordinate department and tends to be twice as high as on a corresponding bank deposit. This is achieved either through a much higher interest rate (fee) or through a combination of interest rates and dividends. In the latter case interest rates are frequently set $10 \%$ above the corresponding bank interest rate (i.e., multiply the bank interest rate by a factor of 1.1). The spread between loan and deposit

\footnotetext{
8 In $199551 \%$ of the 8236 employees of RCFs in Henan Province concurrently held other positions. (Dui nongcun 1996, p. 2)

9 The 33 RCF in Dali County, Shaanxi Province, distinguish between three types of shares: basic shares which carry risk, pay dividends and are usually not to be sold (they accounted for $2.5 \%$ of all external funds at end-1996); "fixed shares" which carry risk, pay usage fees (interest) and dividends, and can be redeemed after one year (37.3\%); and non-fixed shares which are deposits in all but name (20.1\%). (Dali xian 1997)
} 
interest rates is usually low at $1-2 \%$ but higher penalty interest rates come into effect once a loan turns overdue.

Loans extended by RCFs are primarily short-term working capital loans (of 3-6 months duration) to members. But it is frequently understood that the loan will be rolled over once due or that overdue loans will not be pursued aggressively. Across provinces, more than half of all lending typically goes to the agricultural sector and another third to township- and village-run enterprises. Farmers receive a large share of the agricultural loans as well as of the residual loans and across different provinces account for between 40 and $96 \%$ of all lending. (See Table 1.)

RCFs have extensive branch networks covering several townships and villages where branches are set up according to their economic viability. Branches have virtually no decision-making authority on loans. This authority rests with the head office in the township or county seat and thus often, given the personnel overlap, with the superordinate department. In many localities several RCFs coexist, such as funds run by the county TVE bureau, the county agricultural department, and the supply and marketing network. Final authority on interest rates and on general policies (such as institutional expansion) then is concentrated in one government office, usually in the agricultural department. The profitdependent dividend may vary from RCF to RCF.

While by 1998 some municipal agricultural departments have set up coordinating RCF offices, provincial-level coordination is rare. In the case of the 32 township and village enterprise (TVE) RCFs in Shaanxi Province the provincial TVE bureau only promotes their cause and circulates development guidelines but does not issue instructions on how 
to run a RCF; nor does it exercise any supervision. No nationwide uniform regulatory framework on RCFs exists. ${ }^{10}$

\section{Extent of rural cooperative funds}

At the end of 1994 more than one third of all townships and slightly below one fifth of all villages nationwide had a RCF (or a RCF branch). But the spread of RCFs is not uniform across the country. By the end of $1995,65 \%$ of all municipalities and $56 \%$ of all counties in Sichuan Province had established "joint" cooperative funds (hezuo jijinhui lianhehui) each coordinating several RCFs. By the end of 1996, 712 townships in Shaanxi Province, accounting for 32\% of all townships, had established RCFs. In Henan Province $63 \%$ of all counties, $32 \%$ of all townships, and $65 \%$ of all villages had established one or more RCF by September 1995 (Dui nongcun, 1996). In Xinjiang Province, 44\% of all townships and $45 \%$ of all villages had some form of RCF by the end of 1996. In other provinces, such as in Hebei Province, RCFs exist but have remained on a smaller scale. ${ }^{11}$

While some local data on the volume of funds held at RCFs can be pieced together, official nationwide or systematic data is not available.

10 The Agricultural Ministry handles RCF matters within its Rural Cooperative Economy Guidance Office (nongcun hezuo jingji zhidaosi) which has established a Rural Economic Administration Station (nongcun jingji guanli zongzhan) as a semiindependent administrative facility (shiye danwei). The central bank, the People's Bank of China (PBC), covers RCFs in its Rural Cooperative Finance Administrative Bureau (nongcun hezuo jinrong guanli $j u$ ).

11 The nationwide data is from Nongcun hezuo jingji yingying guanli, no. 10 (Oct. 1995), p. 13. For Sichuan Province see Guo and Yang (1997) on Sichuan Province, for Shaanxi Province ShGov 97/7/21 (SXNJ 1997, p. 101 reports 700 townships with RCFs), for Henan Province Dui nongcun (1996), and for Xinjiang Province Xinjiang nianjian 1997 (1997, p. 160). 
Nationwide deposits at RCFs appear equivalent to about 0.73 to $2.92 \%$ of total deposits at financial institutions in China. (See Table 2.) The range reflects the unofficial estimates of economists in the central bank (the lower estimate) and of economists in the Agricultural Ministry (the upper estimate).

Across provinces, deposits at RCFs are equivalent to between half a percent and six percent of deposits in the formal financial sector. The relative size of RCFs has been increasing over the years in all provinces for which RCF data is available. RCFs in Shaanxi Province are insignificant according to all sources, but the claim that the 32 TVE RCFs account for perhaps less than $3 \%$ of the number of RCFs in Shaanxi Province while for almost $90 \%$ of all deposits at RCFs is not credible. If the average size of a TVE RCF were about the average size of all RCFs in Shaanxi Province, which is likely, and if the TVE RCF deposit data were correct, then deposits at all RCFs in Shaanxi Province would have been equivalent to approximately $5 \%$ of all deposits in the formal financial sector around the end of 1996. Within Shaanxi Province, RCFs in Weinan Municipality by the end of 1997 have attracted deposits equivalent to about $27 \%$ of deposits in the formal financial system. ${ }^{12}$ Overall, published data is more likely to under-than to over-estimate the extent of RCFs given the central-local and intra-central conflicts discussed in the following two sections.

12 Data on the 1997 increase in deposits in the formal financial system vs. the RCFs confirm the size of the RCF sector in Weinan Municipality. See PBC Weinan Municipality (1998) and Wu (1997). 


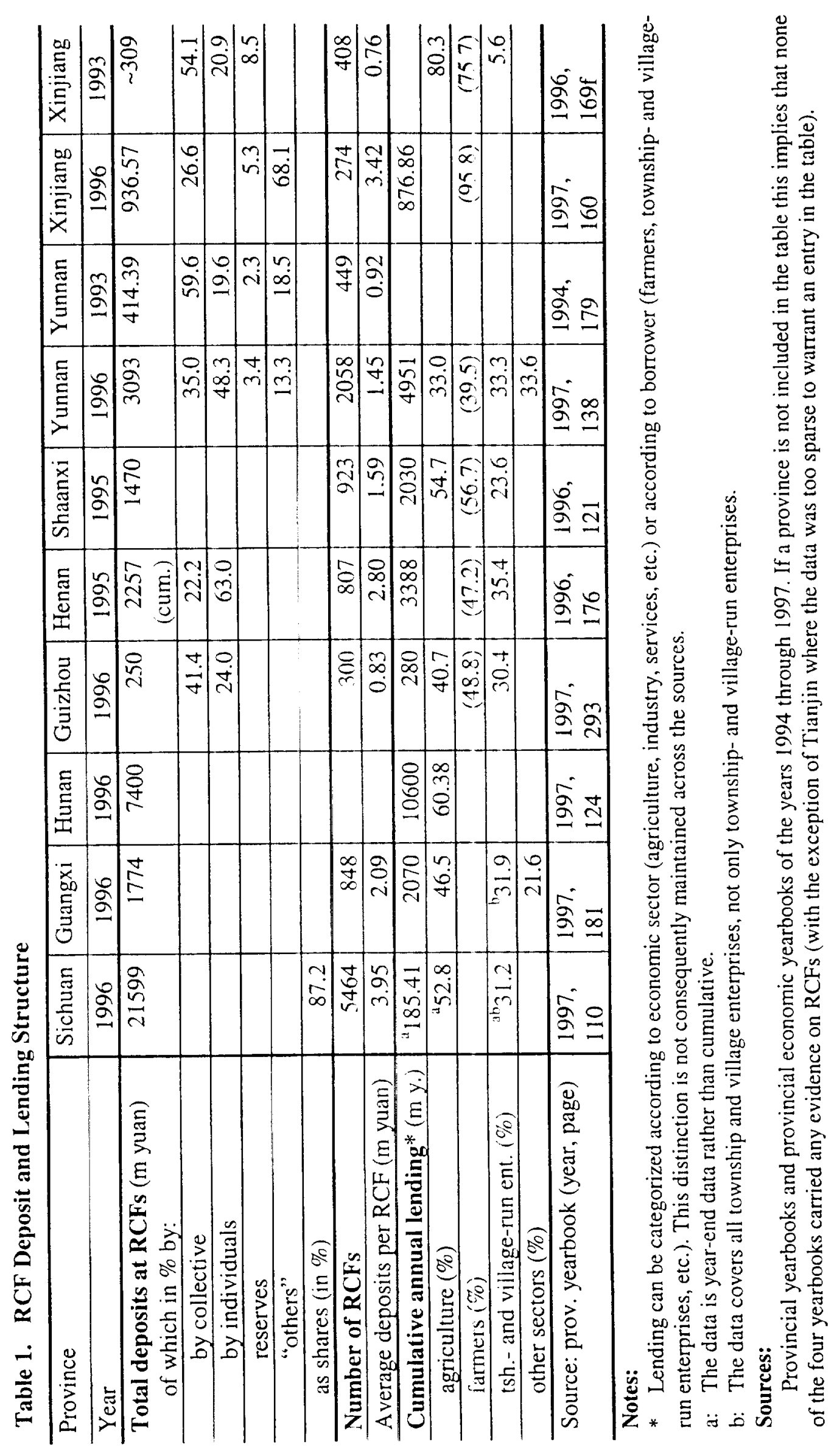


Table 2. Extent of Rural Cooperative Funds

\begin{tabular}{|c|c|c|c|c|c|}
\hline \multirow[t]{2}{*}{ Locality } & \multirow[t]{2}{*}{ Date } & \multirow{2}{*}{$\begin{array}{c}\text { RCFs } \\
(\#)\end{array}$} & \multicolumn{2}{|c|}{ Deposits (m yuan) at } & \multirow{2}{*}{$\begin{array}{r}\mathrm{a} / \mathrm{b} \\
(\%) \\
\end{array}$} \\
\hline & & & RCFs [a] & banks [b] & \\
\hline \multicolumn{6}{|l|}{ Nationwide } \\
\hline & end-1990 & & $8-10,000$ & $1,401,260$ & $0.57-0.71$ \\
\hline & early 1990s & & 20,000 & & \\
\hline & end-1994 & 17,800 & & & \\
\hline & 1995 & & 80,000 & $5,386,220$ & 1.49 \\
\hline & end-1995 & & $\sim 72,700$ & $5,386,220$ & 1.35 \\
\hline & mid-1997 & & 200,000 & $6,857,120$ & 2.92 \\
\hline & mid-1997 & & $50-70,000$ & $6,857,120$ & $0.73-1.02$ \\
\hline \multicolumn{6}{|l|}{ Provinces } \\
\hline Tianjin & end-1993 & 181 & 240 & 58,612 & 0.41 \\
\hline \multirow[t]{3}{*}{ Sichuan } & end-1994 & 4966 & 6000 & 183,800 & 3.26 \\
\hline & end- 1995 & 5349 & 14526 & 250,400 & 5.80 \\
\hline & end-1996 & & 21599 & 314,000 & 6.88 \\
\hline \multirow[t]{4}{*}{ Henan } & end-1993 & 426 & 476 & 114,366 & 0.42 \\
\hline & end-1994 & 548 & 569 & 160,295 & 0.35 \\
\hline & $9 / 95$ & 74 & 1828 & 213,169 & 0.86 \\
\hline & end-1995 & 807 & 2257 & 270,765 & 0.83 \\
\hline \multirow[t]{3}{*}{ Hunan } & end- 1993 & & 676.77 & 72,151 & 0.94 \\
\hline & end-1994 & & 1968 & 98,453 & 2.00 \\
\hline & end-1995 & 2750 & 4000 & 124,436 & 3.21 \\
\hline \multirow[t]{2}{*}{ Guangxi } & end-1993 & 588 & 260 & 66,534 & 0.39 \\
\hline & end 1996 & 848 & 1774 & 136,117 & 1.30 \\
\hline \multirow[t]{2}{*}{ Guizhou } & end-1995 & 70 & 70 & 47,821 & 0.15 \\
\hline & end-1996 & 300 & 250 & 58,626 & 0.43 \\
\hline \multirow[t]{4}{*}{ Yunnan } & end. 1993 & 449 & 414.39 & 59,356 & 0.70 \\
\hline & end 1994 & 1160 & 1280 & 84,115 & 1.52 \\
\hline & end 1995 & 1792 & 2000 & 118,724 & 1.68 \\
\hline & end 1996 & 2136 & 3093 & 153,959 & 2.01 \\
\hline \multirow[t]{4}{*}{ Xinjiang } & end 1993 & 408 & 128.72 & 44,068 & 0.29 \\
\hline & end 1994 & 1034 & 442.31 & 63,444 & 0.70 \\
\hline & end 1995 & 190 & 808.34 & 83,842 & 0.96 \\
\hline & end 1996 & 274 & 936.57 & 101,247 & 0.93 \\
\hline Anhui & end 1996 & 510 & 510 & 142,070 & 0.36 \\
\hline \multirow[t]{6}{*}{ Shaanxi } & end-1988 & 370 & 40 & 21,034 & 0.19 \\
\hline & end-1993 & & 323 & 92,382 & 0.35 \\
\hline & end -1994 & & 764 & 120,682 & 0.63 \\
\hline & end-1995 & 923 & 1470 & 156,909 & 0.94 \\
\hline & end-1996 & 900 & 2000 & 205,399 & 0.97 \\
\hline & end- 1996 & 1129 & 286 & 205,399 & 0.14 \\
\hline 32 TVE RCFs & mid-1997 & 32 & 250 & 205,399 & 0.12 \\
\hline \multicolumn{6}{|c|}{ Shaanxi Province, subprovincial localities } \\
\hline Xi'an Municipality & mid-199i & & $\sim 100$ & 61,998 & 0.16 \\
\hline Weinan Municip. & end-1996 & 214 & 1091 & 8,530 & 12.79 \\
\hline Weinan Municip. & end-1997 & 450 & 2300 & 8,530 & 26.96 \\
\hline
\end{tabular}


In the case of nationwide data banks consist of state banks and rural credit cooperatives (RCCs); these comprise the PBC, the four state commercial banks, urban cooperative banks, urban credit cooperatives, post office deposits, financial trust and investment companies. finance companies, and financial leasing companies No definition is available for the provincial and subprovincial tiers

Sources (for RCF data; for bank data):

Nationwide:

End-1990: Xu and Deng (1994), p. 10, 84 (approx. 1/4 of all townships has at least one RCF); ZGJRNJ 1997, 464.

Early 1990s: unofficial estimate by an economist with the Agricultural Ministry.

End-1994: Nongcun hezuo jingji jingying guanli no. 10 (Oct. 1995), p. 13.

1995: unofficial estimate by an economist with the Agricultural Ministry; ZGJRNJ 1997, 464.

End-1995: Guo and Yang (1997); ZGJRNJ 1997, 464.

Mid-1997: unofficial estimate by an economist with the Agricultural Ministry; ZGJRNJ 1997, 464 (end-1996).

Mid-1997: unofficial PBC estimate; ZGJRNJ 1997, 464 (end-1996).

Provinces:

Tianjin, end-1993: Tianjin jingji nianjian 1994, 151; ZGJRNJ 1997, 156.

Sichuan, end-1994: Sichuan nianjian 1995, 109; ZGJRNJ '1997, 232f, 236.

end-1995: Sichuan nianjian 1996, 109; ZGJRNJ 1997, 232f, 236.

end-1996: Sichuan nianjian 1997, 110; ZGJRNJ 1997, $232 \mathrm{f}, 236$.

Henan, end-1993: Henan nianjian 1994, 112; ZGJRNJ 1997, 2 l0. end-1994: Henan nianjian 1995, 115, ZGJRNJ 1997, 210.

9/95: Dui nongcun (1996); ZGJRNJ 1996, 210.

end-1995: Henan nianjian 1996, 176. ZGJRNJ 1997, 210.

Hunan, end-1993: Hunan nianjian 1994, 219; ZGJRNJ 1997, 216. end-1994: Hunan nianjian 1995, 157; ZGJRNJ 1997, 216.

end-1995: Hunan nianjian 1996, 118 (registered RCFs); ZGJRNJ 1997, 216

Guangxi, end-1993: Guangxi nianjian 1944, 343; ZGJRNJ 1994, 224. end-1996: Guangxi nianjian 1997, 191; ZGJRNJ 1997. 229.

Guizhou, end-1995: Guizhou nianjian 1997, 297; ZGJR VJ 1997, 239. end-1996: Guizhou nianjian 1997. 293; ZGJRNJ 1997. 239.

Yunnan, end-1993: Yunnan nianjiun 1994, 179; ZGJRNJ 1997, 241. end-1994: Yunnan nianjian 1995, 185f; ZGJRNJ 1997.241. end-1995: Yunnan nianian 1996, 141: ZCJJRNJ 1997, 241. end-1996: Yunnan nianjian 1997, 138; ZGJRNJ 19)7, 241.

Xinjiang, end-1993: Xinjiang nianjian 1994, 169; ZGJRNJ 1997, 258. end-1994: Xinjiang nianjian 1995, 137; ZGJRNJ 1'997, 258. end-1995: Xinjiang nianjian 1996, 180; ZGJRNJ 1997, 258. end-1996: Ximjiang nianjian 1997, 160; ZGJRNJ 1997, 258.

Anhui, end-1996: Nongcun hezuo jingji jingying guanli. \#8/1997, 23; ZGJRNJ 1997, 195.

Shaanxi, end-1988: Shaunxi ribao 89/5/13; SXTJNJ 1990, 407, 409.

end-1993: Shaanxi nianjian 1994,97; ZGJRNJ 1957,246f.

end-1994: Shaanxi nianjian 1995, 122; ZJJJRNJ 1997, $246 \mathrm{f}$. end-1995: Shaanxi nianjian 1996, 121; ZGJRNJ 1997, $246 \mathrm{f}$. end-1996: Shaanxi nianjian 1997. 101; ZGJRNJ 1997, $246 \mathrm{f}$. end-1996: Fan and Xu (1997); ZGJRNJ 1997,2461

32 TVE RCFs, mid-1997: Shianxi Province TVE Administration Bureau 10 June 1997 (one year after general promotion); ZGJRNJ 1997, $246 \mathrm{f}$ (end-1996).

Xi'an Municipality, mid-1997: XATJNJ 1997, 373 (enc-1996)

Weinan Municipality, end-1996: Wu 1997; Shaanxi nianjian 1997, 349. end-1997: Zhongguo renmin yinhang Weinan shi fenhang ketizu 1998 (235 RCFs +215 other cooperative funds and financial institutions); Shaanxi nianjian 1997.349 


\section{Central-Local Dichotomy}

Why did RCFs in many localities grow so rapidly in recent years? One reason is the increasing scarcity of formal financial sector funding. Following a series of illegal practices at the lower-level tiers of the banking system, the formal financial sector was re-centralized in 1994. All refinancing of financial institutions by the PBC now occurs on the central tier. Commercial bank headquarters and provincial branches since 1994 retain part of the annual increase in credit plan limits for own lending which is then financed through a "second-tier minimum reserve" levied on lower-level tier branches. Decisionmaking authority on individual loans has likewise been re-centralized.

In practice, these changes frequently imply a lack of lending allowance, a lack of funds, and a lack of decision-making authority at the lowest-level tier bank branches, in particular on the county level with its offices in townships. The data in Table 3 documents the increasing relative scarcity of formal financial sector funds in the countryside beginning in 1994. While nationwide formal financial sector lending increased by $24 \%$ in both 1994 and 1995, and by $21 \%$ in 1996, Agricultural Bank of China (ABC) lending to TVEs peaked in 1993 at a growth rate far above the nationwide formal financial sector loan growth rate to fall below the nationwide growth rate in 1994 through 1996; the growth rate of lending by rural credit cooperatives (RCCs) to TVEs likewise fell dramatically from its peak in 1994 to below the nationwide average in 1995. Viewed from the point of view of township- and village-run enterprises, ${ }^{13}$ the only type of borrower for which balance sheet data is available, the annual

13 Township- and village-run enterprises accounted for $58 \%$ of total value-added by TVEs in 1996. (ZGXZQYNJ 1997, p. 129) Balance sheet data for joint enterprises and individual- 
growth rate of bank loans (from any formal financial sector institution) dropped sharply from $72 \%$ in 1993 to $11 \%$ in 1994, $9 \%$ in 1995, and $15 \%$ in 1996 . The share of bank loans in total liabilities and capital fell by 14\% in 1995 and by another $2 \%$ in 1996.

The scarcity of formal financial sector funding is even more striking once output changes are taken into account. Nationwide, the ratio of GDP to formal financial sector lending has remained remarkably constant between 1.01 and 1.16 in the period from 1990 to 1996 , with a small rise from 1.05 in 1993 to 1.15 in 1994 (a 10\% deterioration) and to 1.16 in 1995. Township- and villagerun enterprises, on the other hand, not only add twice as much value per formal financial sector loan than the nationwide average, but furthermore show a much stronger deterioration in the ratio--by $39 \%-$ in 1994 , continuing into $1995 .^{14}$

The limited exposure of the formal financial sector at the lower-level administrative tiers reflects a fundamental central-local dichotomy. The formal financial sector regulated if not owned by the central government traditionally lends to the state-owned enterprises under an implicit government lending guarantee as well as loan repayment guarantee. On the other hand, neither township nor village government or individuals may establish financial institutions, and the central government does not regulate on TVEs. Formal financial sector institutions when lending to TVEs or households thus are not lending to "members of the same family," and lack the implicit government loan repayment guarantee.

owned enterprises in the countryside are not available; formal financial sector lending to these enterprises is likely to be very small.

14 The 1994 vs. 1993 comparison is based on gross output value data as value-added data is not available; the relative changes in the gross output value ratio and the value-added ratio in 1995 over 1994, when both time series are available, are almost equal (a $21.6 \%$ deterioration vs. a $22.3 \%$ deterioration or a $18.6 \%$ deterioration if the lacking Shanghai data in 1994 were approximated as outlined in the notes to Table 3 ). This suggests that relative changes in the ratio of gross output value to formal sector lending prior to 1995 are likely to be a good approximation to the relative changes in a ratio based on value-added. 
While the bias of the formal financial sector is starving local enterprises and farmers of development funds, economic development on the other hand continues to be a major issue for local governments and Party Committees. The unusually sluggish growth of 'TVEs in many provinces in recent years has contributed to a sense of urgency. But localities increasingly lack government funds to promote economic development. The 1994 tax reform massively raised the share of total revenues collected by the center (from 22.02\% in 1993 to $55.70 \%$ in 1994) which then redistributed the funds to provinces to an extent that the local share of expenditures fell only two percentage points (from $71.74 \%$ in 1993 to $69.71 \%$ in 1994). (ZGTJNJ 1998,281 )

The county tier was hard hit by the changes in revenue allocation. As Table 4 shows, in six out of ten provinces for which county tier data can be calculated the ratio of the county tier share of total provincial expenditures to the county tier share of total provincial revenues increased significantly in 1994 over 1993, while in three other provinces the ratio decreased, but only slightly. The last provincial-level entity, Tianjin, appears to have conducted a major redistribution of revenues to the county tier. ${ }^{15}$ The general increase in the ratio was primarily due to a disproportionate decrease in revenues rather than a disproportionate increase in expenditures (see Table 5). Unless central government redistribution of revenues reached the county tier disproportionally this suggests that the county tier faced very strong pressures in 1994 to find new ways to finance local economic development. This development was partly reversed by 1996 only.

15 The mean ratio of 1994 is significantly different from the mean ratio of 1993 at the 5\% significance level (two-tailed test, excluding Tianjin). 


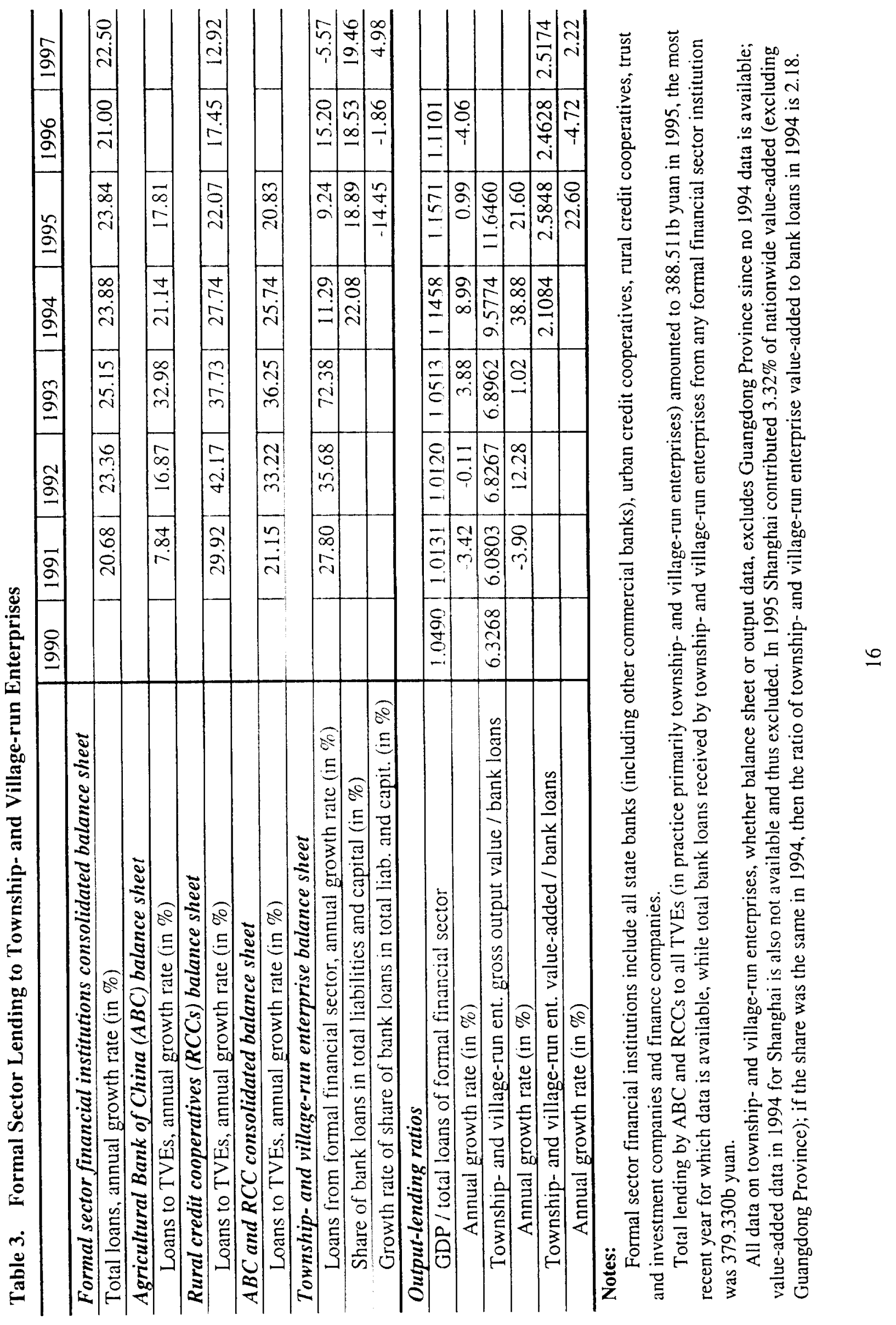




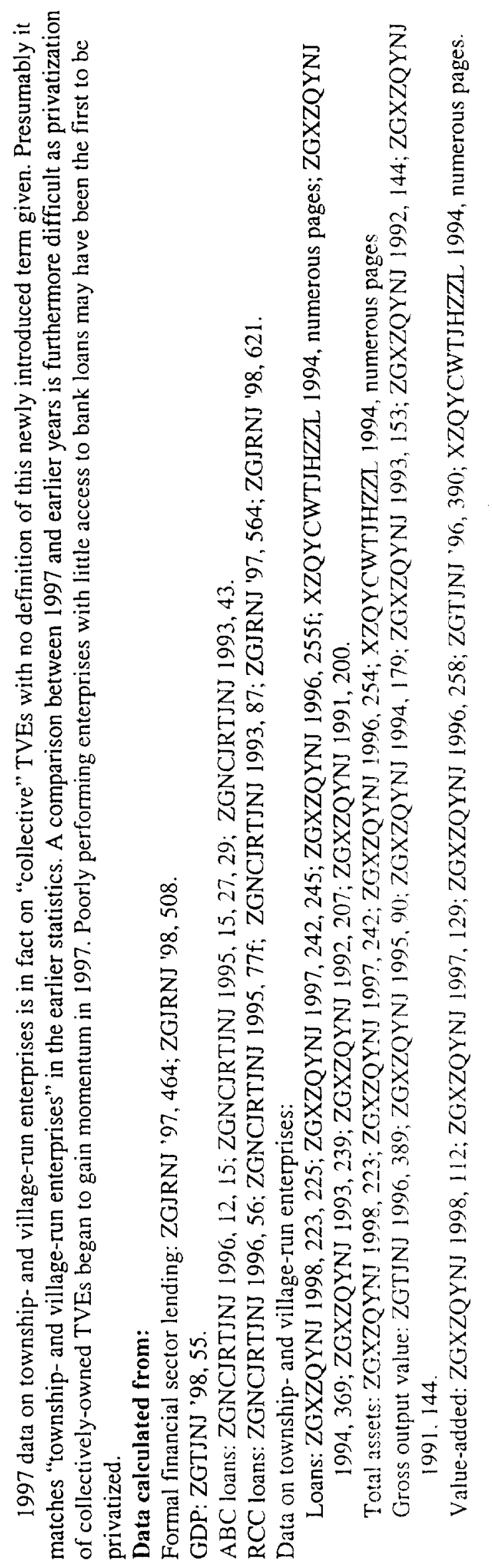


Table 4. Ratio of County Tier Share in Provincial Expenditures to County Tier Share of Provincial Revenues

\begin{tabular}{l|r|r|r|r|r}
\hline & 1993 & 1994 & 1996 & \multicolumn{2}{|c}{ Growth rates (\%) } \\
\cline { 5 - 6 } & & & & $94 / 93$ & $96 / 94$ \\
\hline Henan & 1.12 & 1.00 & 0.94 & -11.12 & -5.46 \\
\hline Xinjiang & 1.49 & 2.15 & 1.80 & 44.05 & -16.24 \\
\hline Yunnan & 1.55 & 1.41 & 1.00 & -8.73 & -29.25 \\
\hline Zhejiang & 0.56 & 1.17 & 1.82 & 108.21 & 55.46 \\
\hline Ningxia & 1.26 & 1.50 & 1.07 & 18.99 & -28.67 \\
\hline Anhui & 1.09 & 1.70 & 1.32 & 56.03 & -22.38 \\
\hline Sichuan & 0.10 & & 0.79 & & \\
\hline Shaanxi & 0.98 & 0.95 & 0.89 & -2.87 & -6.84 \\
\hline Jiangxi & 0.73 & 1.35 & 0.78 & 83.96 & -42.35 \\
\hline Hebei & 1.29 & 2.17 & 0.78 & 68.63 & -63.85 \\
\hline Tianjin & 6.44 & 0.97 & 0.98 & -84.94 & 1.21 \\
\hline
\end{tabular}

Sources: Calculated from individual provincial statistical yearbooks. For all excluded provinces the data is not available in their statistical yearbooks.

Table 5. Growth Rates of Local Fiscal Expenditures and Revenues (in \%)

\begin{tabular}{|c|c|c|c|c|c|c|c|c|}
\hline & \multicolumn{4}{|c|}{1994 vs. 1993} & \multicolumn{4}{|c|}{1996 vs. 1994} \\
\hline & \multicolumn{2}{|c|}{ Expenditures } & \multicolumn{2}{|c|}{ Revenues } & \multicolumn{2}{|c|}{ Expenditures } & \multicolumn{2}{|c|}{ Revenues } \\
\hline & Prov. & County & Prov. & County & Prov. & Cou. & Prov. & Cou. \\
\hline Henan & 14.82 & 13.34 & -32.94 & -25.52 & 50.51 & 60.17 & 73.60 & 95.42 \\
\hline Xinjiang & 12.94 & 13.42 & 12.94 & -21.26 & 48.79 & 77.35 & 48.79 & 111.74 \\
\hline Yunnan & 1.55 & 10.09 & -62.57 & -55.55 & 32.72 & 65.64 & 69.50 & 198.98 \\
\hline Zhejiang & 22.38 & 12.85 & 25.65 & -44.35 & 39.65 & 135.21 & 39.33 & 50.95 \\
\hline Ningxia & -0.11 & 4.31 & 34.52 & 18.05 & 52.36 & 38.58 & -13.13 & 10.76 \\
\hline Anhui & 29.53 & 24.51 & 48.87 & -8.29 & 91.60 & 207.84 & 77.22 & 266.82 \\
\hline Sichuan & 13.26 & & -50.93 & & 4.17 & & 55.06 & \\
\hline Shaanxi & 13.42 & 10.84 & -32.29 & -31.87 & 42.42 & 34.20 & 58.73 & 60.55 \\
\hline Jiangxi & 12.37 & 12.98 & 35.02 & -26.21 & 43.27 & 46.23 & -13.06 & 53.93 \\
\hline Hebei & 13.05 & 2.31 & 12.00 & -39.90 & 44.18 & -13.11 & -7.00 & 55.02 \\
\hline Tianjin & 41.07 & 36.17 & -33.10 & 328.78 & 56.53 & 51.59 & 57.60 & 50.81 \\
\hline All China & \multicolumn{2}{|c|}{24.78} & \multicolumn{2}{|c|}{19.99} & \multicolumn{2}{|c|}{37.03} & \multicolumn{2}{|c|}{41.97} \\
\hline
\end{tabular}

Sources: Calculated from individual provincial statistical yearbooks. For all excluded provinces the data is not available in their statistical yearbooks. Nationwide data is from ZGTJNJ $(1998,281)$. 
These developments in 1994 did nothing to alleviate tight budgets on the county tier-county and township tier budgets are frequently described as "daily necessities" (chifan) budgets, barely sufficient to cover administrative costs, with little or no discretionary spending. Lacking fiscal funds, increased lending by financial institutions often remained the only channel to support local economic development. With ever less local government influence on re-centralized formal financial sector decisions on lending, RCFs offer an opportunity to raise significant sources of extra funding for township-and village-run enterprises (mainly provided by specialized TVE cooperative funds) as well as for individual-owned enterprises, jointly-owned enterprises and farmers (mainly provided by more general-purpose RCFs).

Tax arrangements likewise encourage the establishment of RCFs. RCFs pay a business tax of $5 \%$ on interest income from lending activities to local governments as all other financial institutions do (Wang and Yang 1997, 195). But the 55\% income tax of the state commercial banks, calculated for each bank on the national level to include the income of all branches, is submitted to the state tax office (guojia shuiwuju) and turns into central government budget revenues. RCFs, on the other hand, pay their income tax to the local (provincial and subprovincial) tax office (difang shuiwuju). ${ }^{16}$ (State tax office 95/2/10) In practice, local governments in support of theit RCFs frequently do not collect income

16 The maximum income tax rate for RCFs as non-financial institutions is $33 \%$; since the operation of one cooperative fund is relatively small, the reduced tax rate of 27 or $18 \%$ may apply. (The income tax rate is $27 \%$ if the taxable income is 100,000 yuan or less, and $18 \%$ if the taxable income is 30,000 yuan or less. (State tax office 95/5/18))

Wang and Yang (1997), the tax almanac used by local tax authorities in at least $\mathrm{Xi}$ ' an Municipality includes 34 pages of tax exemptions (pp. 400-434), including an exception for RCCs in poverty areas (RCCs otherwise face an income tax of $33 \%$ ), 
taxes from RCFs but allow them to retain all profit after paying the business tax. RCFs likewise tend to escape the various local government levies on rural enterprises; thus the TVE bureau rarely collects the administrative fee of $0.7 \%$ of income from TVE RCFs that it levies on TVEs.

Besides the local government most local actors, in particular enterprises and households have incentives to support local RCFs. Enterprises benefit from a high return on deposits, the availability of loans and the independence from the state commercial banks as extended arms of the central government; state regulations on the use of cash by non-households find no application in RCFs. Households, like enterprises, benefit from a higher return on deposits and the availability of loans.

Of all local actors, the PBC branch is perhaps the one most reluctant to tolerate or even support the RCFs. The establishment of a financial institution requires $\mathrm{PBC}$ approval and the RCFs are de facto financial institutions. While the county PBC' branch may prefer to maintain good relations with the local government, the direct vertical leadership structure within the PBC ensures a minimal amount of county branch compliance with the instructions of the $\mathrm{PBC}$ headquarters and pressure on the county branch to act thus is high. For example, the PBC branch of a poverty county in Shaanxi Province, after prompting by its superior municipal branch, wrote to the county government in late 1996 proposing that "the county government organize the relevant departments to in accordance with the law ban and investigate the illegal financial

but on cooperative funds only states that the Agricultural Ministry is responsible for determining the relevant policies and laws and regulations (p. 423). 
institutions in our county. ${ }^{17}$ It was, however, careful to point out that this excluded the "rural cooperative funds" presumably directly under the agricultural department; the TVE cooperative fund was illegal. As in other counties, the local government was highly protective of the only financing source of local economic growth under its control. In the absence of a conclusive central policy the document had no immediate effects. $^{18}$

17 A list of illegal financial institutions was attached. Twenty copies of the document were forwarded to the county Party Committee, the county People's Congress, the municipal PBC branch, and leading employees of the county PBC branch itself. 18 In response to the widespread growth of the RCFs, the PBC of the same municipality demonstratively issued golden plaques to all "legal" financial institutions - but not to cooperative funds. The signs are displayed in prominent position above the banks' front doors and read " $X$ branch is a legal financial institution approved by the PBC. Deposits at this institution enjoy the protection of the laws of the state. [Signed:] PBC branch, Y municipality." As of 1998 such plaques violate Art. 18 of a PBC regulation on deposit withdrawal (PBC 98/2/23) which prohibits $\mathrm{PBC}$ branches from issuing any deposit guarantees. 


\section{Intra-Central Conflict}

The rapid establishment and growth of RCFs in recent years was accommodated by a lack of agreement between central ministries on how to regulate RCFs. In 1986 Chen Muhua as governor of the PBC reached an agreement with the Agricultural Ministry to accept RCFs as nonfinancial institutions under the condition that they would not publicly solicit deposits and remain small, local mutual-aid organizations. SC $88 / 9 / 17$ as the earliest piece of central regulation specifies that the establishment of a RCF requires approval by the $\mathrm{PBC}$ and registration with the Civil Affairs Administration; RCFs are to report on their finances to these two institutions annually, and to accept their supervision. While RCFs were explicitly denoted "social organization legal persons" (shehui tuanti faren), the question of whether they are financial institutions was not raised. PBC and Civil Affairs Administration were entrusted with the implementation of the SC decree and with enactment of implementing instructions. The Agricultural Ministry was not mentioned in this decree.

Shifting authority over RCFs to the Agricultural Ministry

This arrangement remained unchallenged until the mid-1990s. The Eighth Plenum of the Thirteenth Central Committee in November 1991 confirmed the legitimacy of the RCFs ("the rural cooperative funds shall be continued;" CCPCC 91/11/19) and the SC in its blueprint for financial reform (SC 93/12/25) added a new twist by stating that RCFs are not 
financial institutions, cannot collect deposits, and cannot extend loans. But in early 1994 the development of the RCFs was given new impetus when the Chinese Communist Party Central Committee (CCPCC) and the $\mathrm{SC}$ decided that "the rural cooperative funds shall be turned into social, mutual cooperative funding organizations (shehuixing de zijin huzhu hezuo zuzhi); they do not conduct deposit business but serve agriculture and farmers in the locality." (CCPCC 1994)

Authority over RCF matters gradually shifted to the Agricultural Ministry. Agricultural Ministry and PBC together restated that RCFs are not financial institutions and assigned responsibility for RCFs to the Agricultural Ministry (AgMin 1994). In 1995 the Agricultural Ministry followed up with a regulation on the registration of the RCFs (AgMin 95/4/19). While the accompanying circular asked that the superordinate department of the RCF strive for PBC support, the regulation states very unambiguously that establishment of a RCF only requires approval by the township government and then registration with the county-level agricultural administration. Supervision over RCFs is exercised by the agricultural departments; no mentioning is made of the $\mathrm{PBC}$ which in the previous regulation (AgMin 1994) was still named as exercising supervisory authority.

The change in approval and registration procedures may well reflect earlier, dispersed local developments possibly in violation of the 1988 $\mathrm{SC}$ regulations. For example, the Hebei Province Party Committee as early as on 6 July 1992 urged all local governments and departments to "let the rural cooperative funds develop as quickly as possible," and "localities which have not yet acted are to implement pilot projects and to do all they can so that cooperative funds will be widespread one or two years from now." This decision in the absence of any such nationwide 
policy suggests that RCFs may have begun to grow beyond their originally intended scope of administering formerly collectively owned property almost from the date of their inception, with little regard for proper approval and registration procedures. ${ }^{19}$ Financial sector policies never envisaged such developments.

The clarification that the RCF is a mutual aid (or cooperative) organization with as superordinate department the Agricultural Ministry allowed the explosive growth of RC'Fs. In many localities government and Party Committee began to openly promote the establishment of RCFs. In 1995 the Shaanxi Province Party Committee and the Shaanxi government, for example, requested that by the end of the eighth FiveYear Plan $60 \%$ of all townships were to have established RCFs (Xi'anGov 95/4/27).

\section{Legal ambiguities and PBC backlash}

The SC in a rural financial reform blueprint (SC 96/8/22) subsequently admonished that RCFs may not collect deposits. If they do, they are to be incorporated into the RCCs. The PBC and the Agricultural Ministry were requested to issue "rural cooperative fund administration regulations" which, however, as of late 1998, have not yet been issued. The Rural Economic Administration Station that handles RCF matters within the Rural Cooperative Economy Guidance Office of the Agricultural Ministry was ordered to stop work and to report to the SC.

19 Tai (1998) reporting on the establishment of a RCF in Xiaoying Village (Liquan County, Xianyang Municipality, Shaanxi Province) in 1990 does not mention any particular approval procedure. The county urgently needed funds to establish its 
While the central government searched for a policy, the growth of the RCFs continued unabated. For example, the Shaanxi Province TVE Bureau in June 1997 encouraged the further growth of the TVE RCFs with as long-term perspective a TVE development fund (Shaanxi Province TVE Administration Bureau 97/6/10).

Such TVE funds were legitimized in the PRC TVE Law passed in late 1996 (NPC 96/10/29). The law allows county-tier and higher-level tier governments to establish TVE development funds. While sources of funding comprise government funds, part of the increase in local TVE taxes, and retained profits, they also include other funds provided by rural collective organizations, TVEs, and farmers (Art. 21). The funds are to be used primarily to support TVEs but the categories are broad enough to encompass other uses (Art. 22). Although no development funds have so far been set up, present TVE cooperative funds easily match these requirements and could simply be renamed if need be. ${ }^{20}$ This pits the PRC TVE Law directly against the PRC PBC Law and the PRC Commercial Bank Law which require PBC approval for all financial institutions. $^{21}$

In mid-1997 the PBC was finally given green light to go ahead and "clean up" the RCFs. In Shaanxi Province the provincial government on 21 July 1997 approved the suggestions of the provincial PBC branch and Agricultural Bureau on "cleaning up" the RCFs between August and

\footnotetext{
"dragon head" enterprises so it started a RCF open to the public based on the principle "voluntarily purchase shares, freely withdraw shares."

20 Jiangsu Province, which does not have TVE RCF, is presently considering the establishment of such a TVE development fund on the provincial tier.

21 Art. 31 of the PRC PBC Law (NPC 95/3/18) requires PBC approval for the establishment, transformation, and termination of all financial institutions. According to Art. 11 of the PRC Commercial Bank Law (NPC 95/5/10) "without PBC approval no unit or person may collect deposits from the public or conduct other commercial banking business."
} 
December 1997. On 5 October 1997 the Shaanxi provincial government approved a further "adjustment of the financial order" as suggested by the PBC. This led to a flurry of circulars by government departments on all tiers (such as by the Shaanxi Province TVE Administration Bureau on 29 November 1997) as well as to actual changes in RCF practices. Some RCFs temporarily halted all lending in late 1997 until the investigations were completed.

The most visible result is a slowdown in the rapid expansion of RCFs achieved through an enforced reduction in deposit rates offered by RCFs. While the Shaanxi Province government had requested that the "usage fees" paid on deposits be comparable to the interest rates of the banking system, in practice the former still exceed the latter, but far less so than before. ${ }^{22}$ The payment of dividends continues without limitations for members (permanent shareholders). Lending now is limited to members but this can be circumvented through low membership shareholding requirements. PBC and agricultural departments in Shaanxi Province also requested a clear internal administrative structure with shareholder meeting, Board of Directors and Supervisory Board, while local government and Party leaders are prohibited from holding leadership positions in the RCFs (ShGov 97/7/21).

22 In one particular county in Shaanxi province, RCFs in April 1998 offered "usage fees" of 8.28 to $9 \%$ per annum on "1-year shares" (without dividend payments) while the state-determined interest rate in the financial system on one-year fixed-term deposits was $5.22 \%$.

AgMin and PBC 1994, Art. 7 required RCF "usage fees" to be no higher than the corresponding bank interest rates. The RCFs can evade the spirit of this regulation by paying bank interest rates plus dividends on deposits. Interest rate caps on loans can easily be flouted through handling fees, compensating balances and repayment scheduling. 
Illegal financial institutions?

Decisive new policies were expected from the Fifteenth Party Congress in September 1997 but did not emerge. On 14 October 1998 the Third Plenum of the Fifteenth CCPCC in a major decision on agricultural development avoided placing any clear-cut constraints on RCF development and only stated that "various types of economic entities organized by farmers in shareholding form are a new product of reform and shall be actively supported, receive correct guidance, and be gradually perfected."

But at the same time, the PBC was pushing for RCFs to be dealt with as illegal financial institutions. The SC as early as on 13 July 1998 issued a regulatory framework banning illegal financial institutions and illegal financial activities. While this regulatory framework did not specify which type of quasi-financial institution is illegal, the PBC (with approval of the SC) was quick to issue a circular on 11 August 1998 identifying individual categories of institutions and behavior to be deemed illegal. This circular for the first time explicitly lists individual types of funds as illegal, and issues instructions on how to deal with them.

The circular requests that cooperative funds (jijinhui), mutual aid funds (huzhuzu), savings funds (chujinhui), funds service departments (zijin fuwu bu), share service departments ( $g u j i n f u w u b u)$, clearing centers (jiesuan zhongxin) and investment companies (touzi gongsi), all run by governments and their departments, be cleaned up and reorganized. If any financial activities such as acceptance of deposits from the public or lending are undertaken, these have to stop by the end of June 1999. The circular reconfirms the 1988 SC decision (without 
referring to it) that cooperative funds require $\mathrm{PBC}$ approval and must be registered with the Civil Affairs Administration. All illegal activities and institutions are to be examined in a first step by the end of 1998 and then rectified in a second step by the end of March 1999; the PBC finally is to have checked on the rectification by the end of June $1999 .^{23}$

However, the circular does not resolve the conflict between PBC and Agricultural Ministry. In a short sentence the RCFs-as well as "intermediate institutions" of the finance departments - are explicitly excluded from the reorganization campaign. While the PBC thus managed to start a major campaign against various types of funds run by local governments in an attempt to bridge the central-local chasm, the vast majority of cooperative funds are excluded.

The contradiction between PBC and Agricultural Ministry implies that RCFs in the near future will continue to operate as before. ${ }^{24}$ But the PBC circular, although presenting a three-stage reorganization schedule to be completed by mid-1999, also gives a separate deadline of end-2000 for the whole campaign, one and a half years after completion of the three-stage rectification. This not only suggests that the $\mathrm{PBC}$ is well aware of the uphill struggle it is about to embark on and that the success of the three-stage rectification measures is far from guaranteed even with

\footnotetext{
23 The Shaanxi Province government has taken up the issue on 9 October 1998 with the establishment of a leading group. Municipalities (and prefectures) are required to likewise establish leading groups. Results of the reorganization are to be reported to the provincial government by end-May 1999. Reports in the media on any financial matter including on various types of local funds require prior PBC approval.

24 The differences in the position of the PBC and the Agricultural Ministry carry over to the publications associated with each of the two institutions. For example, publications associated with the PBC, such as the newspaper Jinrong shibao, the nationwide journal Jinrong cankao or the local journal Shaanxi jinrong offer consistently negative survey reports and comments on the RCFs. Publications associated with the agricultural departments, on the other hand, such as the nationwide journal Nongcun hezuo jingji guanli or the local journal Nongcun jingji strike a much more positive note about the development of the RCFs.
} 
the limited number of targets, ${ }^{25}$ but it also raises the possibility that the campaign may enter a new phase after the first three stages. This new phase may then include RCFs, especially if the first phase has brought to light wide-spread irregularities and activities endangering the stability of the financial system. ${ }^{26}$

25 The national supply and marketing cooperative in early 1999 , for example, did not at all require the cooperative funds run by the local supply and marketing cooperatives to be disbanded. All it is concerned about is that funds be no longer "publicly" collected. (Jinrong shibao 13 Jan. 1999)

26 A major difficulty in closing cooperative funds is the fact that the central bank has no authority over these institutions. Closure of illegal financial institutions requires action by public security organs acting in accordance with the criminal code; public security, on the other hand, may not be qual Ified to determine what constitutes an illegal financial institution. The PBC thus needs to first identify the particular institution to be closed and then report to public security for action. See Xinbao (Hong Kong Economic Journal) 21 Nov. 1998 for the legal intricacies. In practice, local public security organs may well drag their feet especially if so encouraged by the local government. 


\section{Economic Implications of RCFs}

The development of RCFs has a number of economic implications. RCFs change the extent and quality of financial intermediation in a locality. The financial health of RCFs affects local economic and social stability. RCFs finally have a number of macroeconomic implications.

\section{Financial intermediation}

The development of RCFs is likely to increase the degree of financial intermediation in a locality because RCFs offer a larger amount of loans to the locality per local deposits than formal financial sector institutions. The volume of RCF loans is equal to $60-90 \%$ of deposits, with the remainder being held as reserves either in cash or with the formal financial sector. $100 \%$ of this lending occurs within the locality. The formal financial sector, on the other hand, retains much fewer funds in the locality. Table 6 attempts to pin down the extent of leakages in the formal financial sector out of rural into urban areas by focusing on the two formal financial sector institutions in the countryside, the $\mathrm{ABC}$ and RCCs.

Rural credit cooperatives in 1996 made loans equivalent to $72 \%$ of deposits. But only a small share of these loans definitely remained in the locality; these are the "TVE loans" which in 1996 were equivalent to $43 \%$ of total deposits only. This share has furthermore fallen significantly from its peak in 1993 at $50 \%$, suggesting that the outflow of funds from rural to urban areas through the RCC network has increased 
since 1994 when the formal financial sector was re-centralized. Most of the "agricultural loans" are likely to serve agricultural procurement (for transfer of agricultural resources to urban households and state-owned industry). "Other loans" may in part go to individuals but also include loans to state-owned enterprises. Overall, of total deposits collected almost exclusively in the countryside, RCCs re-lend perhaps no more than $50 \%$ in the countryside.

The Agricultural Bank of China in 1995, the latest year for which detailed data is available, had a loan-to-deposit ratio of 0.95 . Definitely extended in the countryside were again the TVE loans which were equivalent to $16 \%$ of total deposits only, far down from a peak of $28 \%$ in 1992 and 27\% in 1993, again suggesting an increasing transfer of funds out of the countryside. The largest share of ABC loans still goes to stateowned enterprises either to finance industry and commerce (primarily related to agricultural procurement) or to fund capital construction and technological updating and innovation. ${ }^{27}$ "Agricultural loans" and "other loans" may include some loans to individuals in the countryside, but the $\mathrm{ABC}$ is unlikely to bother with small loans to households. ${ }^{28}$ Even if all agricultural loans and all other loans were viewed as having been extended in the countryside, their share together with TVE loans in total

27 This share dropped significantly in 1994 as much lending related to agricultural procurement was shifted to the Agricultural Development Bank of China (ADBC). Along with these loans, $\mathrm{PBC}$ refinancing of the $\mathrm{ABC}$ (rather than deposits at the $A B C$ ) moved to the $A D B C$, causing the sharp drop in the ratio of (now reduced) loans to (unchanged) deposits.

The ratio of total $A B C$ loans to total deposits at the $A B C$ is still relatively high as RCCs up to and including 1996 deposited all minimum and excess reserves with the $A B C$. These reserves are not included in the "total deposits" at the ABC. Since the separation of $\mathrm{ABC}$ and $\mathrm{RCCs}$ these reserves are held with the $\mathrm{PBC}$; the data discussed here is not affected by this re-organization.

28 According to Jinrong shibao of 11 January $1999,80 \%$ of all loans to agricultural households (nonghu) and $70 \%$ of all loans to TVEs are extended by RCCs. 
deposits would still not exceed $43 \%$, by far less than the share achieved by RCFs.

These figures confirm the outflow of funds from the countryside as well as the significant relative increase in this outflow since 1993. One shortcoming of the data is the fact that even in the early 1990s some deposits at the $\mathrm{ABC}$ may have been urban rather than rural. An alternative then is to use (an estimate of) deposits by rural households with any formal financial sector institution even though such as measure does not include deposits by rural enterprises. ${ }^{29}$ Lending in the countryside also falls far short of this new deposit measure, and the increased leakage of funds from rural to urban areas since 1993 is again confirmed. Lacking exact data on the extent of RCFs, it is not clear whether the positive effect of RCF development on local financial intermediation outweighs the increase in formal financial sector leakage. But any depositing with RCFs rather than the formal financial sector improves the degree of local financial intermediation.

RCFs also help stem the outflow of funds from regions with low economic returns, independent of the rural-urban dichotomy. In the early 1990 s, funds were flowing through the banking system from interior provinces to coastal provinces which enjoyed a higher expected rate of return, leaving interior provinces short of funds to finance even regular production. ${ }^{30}$ Special government funds to TVEs in the central and Western region frequently disappeared as distributors or recipients of these funds lent them to enterprises in the coastal regions. While much of the interbank money market with its transfers to coastal regions was shut down in 1994, the establishment of RCFs under local government and

29 Such rural enterprise deposits should be small as for the case of the ABC and RCC household deposits accounted for $78 \%$ of all deposits in 1995 (see Table 6). 
Party control further reduces capital mobility and thus secures funding for potentially less efficient local enterprises.

RCF development finally implies a change in the composition of the borrower pool in the countryside. RCFs target not only township- and village-run enterprises but as the data in Table 1 attests also, and often primarily, individual entrepreneurs or farmers, a borrower group almost utterly neglected by the formal financial sector. Even though the cost of extending small loans and the risks involved may be high, member support is a primary objective of RCFs. RCFs are furthermore better suited than the formal financial sector to lend to individual households due to their relatively low operating costs. RCFs are routinely subsidized by the local government which may pay for half the employees (who concurrently hold positions in the government), provide offices and renounce its claim to RCF income taxes; RCF remuneration of nongovernment employees is minimal and does not carry any of the housing and social insurance benefits that employees in the formal financial sector enjoy.

30 See, for example, Shaanxi zhengbao no. 16 (August 1993), p. 7. 


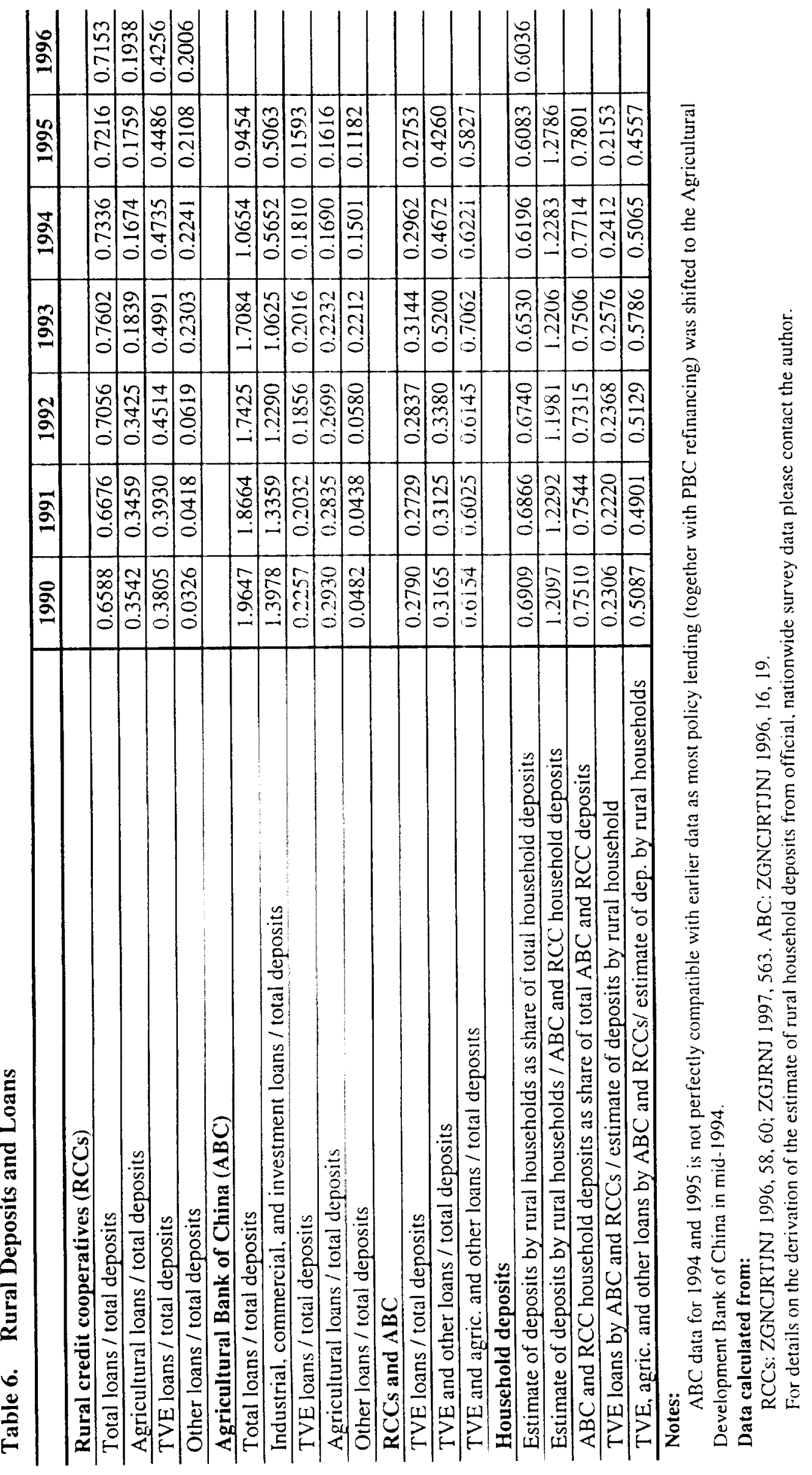


Risk assessment by RCFs may be more accurate than by the formal financial sector, and monitoring and contract enforcement likewise superior. Directors of RCFs are likely to know their borrowers well due to their frequently concurrent position in the government office cooperating with if not supervising the borrower. In one RCF in Shaanxi Province, enterprise personnel has been co-opted as RCF staff, in which case the RCF resembles an enterprise-internal finance department with direct access to household funds. In another RCF, government department retirees on behalf of the RCF pay almost daily, informal visits to the borrower to ensure proper use of the loan. Loan repayment can be enforced not only through the courts but perhaps more easily through the administrative government channels. ${ }^{31}$

RCF financial intermediation comes at a cost, namely high interest rates for the borrower, which in turn may restrict the volume of borrowing and thus local economic growth. However, the obvious counter-side of high interest rates are high returns on deposits for other members of the RCF as long as the spread remains small. ${ }^{32}$ Furthermore, interest rates in the formal financial sector appear to be in practice vastly inflated above the official interest rate through various fees, kick-backs, short maturity with higher penalty interest rates taking effect once a loan is overdue, etc. The level of RCF lending rates may thus be no novelty, with availability of loans for formerly ineligible borrowers a clear improvement.

31 One TVE RCF in Shaanxi Province with approximately 150 loans outstanding in mid-1998 was taking one borrower to court. This was the first case since the establishment of the TVE RCF in 1994 that is has taken a borrower to court. 32 A low spread is ensured by the non-profit motive (all profits are paid out as dividends after statutory increases in reserves). The data requirements to prove the low spread are insurmountable While RCF lending rates are usually fixed by the local government and publicly known, the average return on deposits would have to be calculated a posteriori as a combination of fixed return on deposits, and fixed return plus dividends on member shares. 
A second potential shortcoming of RCF lending is a particular lending bias. Formal financial sector institutions may be observing central government lending preferences biased against the private and rural collective-owned economy, but they also reflect cost considerations regarding loan evaluation and monitoring. RCF lending decisions, on the other hand, may follow lending priorities determined by local governments; lending decisions could be biased towards those borrowers who are closely linked to government departments. RCF funds may furthermore be claimed by local governments and their departments for government projects independent of the economic viability of these projects-in the medium to long run, the leadership responsible will be transferred elsewhere. One, perhaps exceptional example are the RCFs in Nanchong Municipality, Sichuan Province, where up to $20 \%$ of total loans outstanding at the end of May 1998 had gone to government projects such as road building, with $37 \%$ of these loans experiencing repayment difficulties. ${ }^{33}$

33 See Deng (1998). A different report on Gaoping District within this municipality complains that Party and government leaders make RCFs not only extend loans for government projects but also pay for various entertainment events and government consumption of cars and other goods. (Xiang and Ceng 1998) But lending to government projects may occur only in a small number of RCFs and even then on a quite limited scale. Government influence on lending decisions in general may not be pervasive; the provincial-level lending structure shows that the largest share of funds lent usually goes to individual households (see Table 1). 
RCFs have a substantial volume of overdue loans which may reach up to $50 \%$ of all loans. ${ }^{34}$ Perhaps RCF lending is on purpose too short-term (usually below six months) in order to ensure frequent monitoring as well as RCF liquidity. All loans supposedly require collateral or guarantees. This suggests that the qualification of a loan as overdue allows few conclusions on whether it is recoverable or not. Nevertheless, perhaps up to $20 \%$ of all loans are unlikely to be ever repaid. ${ }^{35}$

Any accumulation of dubious loans is facilitated by the often poor quality of decision-making and the frequent lack of internal control mechanisms within the RCF. The Agricultural Ministry only requires the employment of "suitable" professional personnel; head and/or manager (zhuren and/or jingli), accountant, and cashier may not concurrently hold other positions (AgMin 95/4/19, Art. 7). In an earlier regulation, PBC and the Agricultural Ministry required that the member's congress (daibiao dahui) of the RCF elect a Board of Directors (lishihui) and a Board of Supervisors (jianshihui), with the Board of Directors choosing a head responsible for the day-to-day work (AgMin and PBC 1994, Art. 9).

\footnotetext{
34 Only one RCF interviewed was willing to provide information on the extent of overdue loans: they accounted for $2 / 3$ of all loans and $55 \%$ of the total lending volume. Deng (1998) in an article on RCF problems reports an average of $20 \%$ overdue and non-performing loans in all RCFs in Nanchong Municipality, Sichuan Province, at end-May 1998. Xiang and Ceng (1998) document the rapid growth of the overdue and non-performing loan rate in Gaoping District of this Nanchong Municipality with $8 \%$ end-1995, $12 \%$ end-1996, and $27.8 \%$ end-October 1997 . Yu (1997) for 90 RCFs in the 12 counties of Ganzhou Municipality (Jiangxi Province) which had established RCFs (out of 18 counties) gives the share of overdue loans as 40.97\% at end-1996. In individual RCFs the extent of overdue loans can be quite small, such as in the Shuidongjiang Township RCF in Shaodong County, Hunan Province, at $2.66 \%$ end-April 1997.

35 This is an estimate of an official at the Agricultural Ministry; the Agricultural Ministry is not known for criticizing RCFs.
} 
But in practice decision-making and control mechanisms vary dramatically. Few RCF directors have any banking experience and on larger loans the final decision-making authority in the RCFs tends to almost exclusively rest with government officials holding concurrent positions in the RCF. The Board of Directors and other leading personnel is usually handpicked by the township Party committee and government, approved by the county tier superordinate department, and then "democratically elected" by the shareholders. ${ }^{36}$ Few localities insist that township Party and government personnel may not hold any position in the RCF, most take the view that the RCF leadership needs to be identical with the leadership of the Rural Economic Administration Station of the agricultural departments. ${ }^{37}$

In one extreme case in Shaanxi Province a full-time manager is responsible for the day-to-day work and the approval of small loans. But the head of the RCF approves medium-sized loans; he is the chairman of a Board of Trustees (dongshihui), has no banking experience and concurrently holds a government position. Large loans need to be approved by the Board of Trustees in total. In this particular arrangement a Supervisory Board does not exist, nor is there an external audit. In a different RCF in Shaanxi Province, Board of Directors, Board of Trustees, and Supervisory Board have all been established. The full-time Board of Directors is responsible for the day-to-day management, and the part-time Board of Trustees for important decisions as well as recurrent supervision. The chairman of the Board of Directors is a retired banker. The county government auditing bureau carries out an annual external audit.

36 See, for example, Dali xian (1997) and Yang Longsheng (1997).

37 See Chen and Liu (1997) on the first position and Yang Zonglian (1997) on the second position. 
Often poor internal control mechanisms are supplemented by extraordinarily weak external supervision. Local government departments that wish to maintain their control over RCF lending decisions insist that RCFs remain non-financial institutions outside the sphere of influence of the PBC. ${ }^{38}$ While the Agricultural Ministry and the PBC specified in 1994 that the PBC supervises the RCF's business and together with the agricultural departments handles illegal deposit and loan business (AgMin and PBC 1994, Art. 1), the Agricultural Ministry in a regulation in 1995 only mentions the local agricultural departments as supervisory institutions (AgMin 95/4/19, Art. 15). The county agricultural department conducts an annual inspection of the implementation of the statutes and administrative system, this year's business, including profit and losses and profit distribution, and this year's work in general. The RCF neither reports to the $\mathrm{PBC}$ nor receives direct PBC supervision. ${ }^{39}$

Across localities auditing procedures vary vastly. Shaanxi Province has RCFs which conduct no special audit but may report their accounts to the agricultural departments at year-end. In Jimo Municipality, Shandong Province, the joint RCF conducts three complete audits per year and maintains audit files on each RCF (Zhou 1997). In Xiangfan Municipality, Hubei Province, a municipal RCF office attached to the municipal agricultural department conducts an annual audit, sends inspectors to all RCFs once every quarter, and initiates unannounced

\footnotetext{
38 Yang Zonglian (1997) takes a particularly ardent view against any audit by external institutions except the agricultural departments.

39 In at least one municipality in Shaanxi Province an unspecified degree of consultation takes place between the agricultural departments on municipal tier and the municipal PBC branch. This appears to be an exception. Secondary literature on higher-level tier coordination reports exclusively on the establishment of county tier and municipal tier RCF offices within the agricultural departments. (See, for example, Chen and Liu (1997) or Pang, Zhang and Li (1997).
} 
examinations (Chen and Liu 1997). Auditing practice thus varies from internal financial reports only to frequent external audits. However, no audit is ever made by any institution that is not also directly or indirectly involved in the running of the RCF, questioning the quality of any audit.

The accumulation of dubious loans poses a significant long-term solvency problem with implications in the short run. A bad loan problem in a RCF can easily trigger irresolvable liquidity problems once depositors lose confidence in the RCF, well knowing that RCFs are not state-guaranteed financial institutions. In contrast to the formal financial sector, where any short-term liquidity problems are bridged by the $\mathrm{PBC}$ as lender of last resort, the RCF is left to its own means to resolve bank runs. Consequently, RCFs maintain $10 \%$ to $40 \%$ of their assets as deposits at state commercial banks. ${ }^{40}$ RCFs, like state commercial banks, also require depositors to give advance notice in the case of large cash withdrawals. These precautionary measures are sufficient for everyday business. They are, however, insufficient in the case of extraordinary events.

For example, in one particular RCF the manager succeeded in evading all controls and to lend up to a third of the RCF's assets to a friend with the loans subsequently not being repaid on time. The county government and Party Committee had to refrain from taking legal or disciplinary action against the manager for the sole purpose of not publicizing the event. The RCF would not have been able to withstand a bank run and

40 Reserve practices vary from locality to locality and are specified either as maximum lending ratios or as explicit reserve ratios. Thus RCFs in the municipallevel Suizhou City, Hubes Province, may not lend out more than $60 \%$ of the funds collected (Pang, Zhang and Li 1997). RCFs in county-level Taixing City of Taizhou Municipality, Jiangsu Province, maintains a $15 \%$ reserve (and a $80 \%$ lending limit); $5 \%$ reserves are kept as cash in the RCFs or as current deposits at banks and RCCs, $5 \%$ are invested in time deposits at banks and RCCs, and 5\% are maintained by the municipal joint RCF for quick adjustment purposes (Jiang and Wu 1997). 
the county government would not have had the financial prowess to guarantee all loans. A similar instance of misuse of funds in Sichuan Province in 1996 triggered immediate bank runs and required PBC cooperation to be resolved. (Renmin ribao 1996/11/25) In 1997 bank runs on RCFs in Langfang Municipality, Hebei Province, induced the municipal $\mathrm{PBC}$ to ensure that RCF reserves with the formal financial sector would be withdrawable at all times. ${ }^{41}$

Macroeconomic implications of RCF expansion and financial health

While the $\mathrm{PBC}$ is denied any significant role in the supervision of RCFs, bank runs on RCFs impact on PBC operations. RCF failures so far have always triggered PBC-led support and rectification measures as local government finances are insufficient to guarantee RCF deposits. ${ }^{42}$ This raises the issue of moral hazard. RCFs use their competitive advantage over the formal financial sector to gain market share and to advance local economic growth which benefits the local government; but should the RCF fail the PBC is called upon and forced to step in by the sheer magnitude of impending local social disorder. RCFs thus may enjoy the best of two worlds: supervision-free, high-interest rate banking and a safety net in case of failure. Local government departments have incentives to push RCF development to the limit as the costs of failure falls incommensurably on the PBC.

41 See Hebei Economic Yearbook 1998 (Beijing: Zhongguo tongji chubanshe, 1998), p. 60 . The report does not state the cause of the bank runs on the RCFs; perhaps the formal financial sector was unable to repay RCF deposits in the first place?

42 Although the PBC has publicly refused to refinance illiquid RCFs, in emergencies it may well have extended help indirectly through formal financial sector institutions. 
But RCFs also affect PBC operations under normal circumstances. RCF deposits are unreported and therefore not included in money supply measures. If formal financial sector money supply growth is $10 \%$ per year but RCFs gain a market share of $5 \%$ of actual (formal and informal financial sector) deposits in the course of one year, then-assuming the absence of an informal financial sector before-money supply growth is in fact $15.5 \%$ rather than $10 \%$. Money supply growth rates as published by the central bank thus may well be several percentage points off the actual money supply growth rates. Such a divergence could have a substantial effect on any central bank fine-tuning of monetary policy.

RCF development also affects the central bank as well as the central government indirectly via the formal financial sector. RCF growth implies that these funds are not being deposited with the formal financial sector and that, in addition, past deposits with the formal financial sector may be switched to RCFs. Enterprises which know that they are unlikely to obtain a loan from the formal financial sector in the future but that they can rely on RCF funding, may stop paying interest on their formal financial sector loans if not repayment of the principal altogether. The formal financial sector is left with an increasing share of overdue loans and falling profitability. The $\mathrm{PBC}$ as lender of last resort is forced to bridge any liquidity problems in the formal financial sector, while the central government will in the final instance have to pay for the formal financial sector's bad loans. 


\section{Conclusions}

If the rise of the RCFs is in fact accompanied by costs accruing primarily at the PBC and the central government, why did the SC not prevent the RCFs from taking over a significant share of rural finance? The conventional answer is that RCFs, quietly established over the past years, have already grown too large to be dissolved. But why then are they not folded into the RCCs which at present are already under reorganization by the PBC? If RCFs were merged into RCCs, local governments would have no incentives to pressure their township- and village-run enterprises as well as other RCF borrowers into repayment of their RCF loans. Folding RCCs into RCFs, on the other hand, is likely to meet with resistance by local governments which view RCCs as centrally run institutions and have no incentive to take over responsibility for the RCCs' accumulated bad loans.

Retaining RCFs as separate non-financial institutions has advantages. Efficiently run RCFs provide rural enterprises neglected by the formal financial sector with loans at little above formal financial sector interest rates, thereby preventing the spread of less acceptable forms of informal finance charging usury rates. The central government may also realize that it will never be able to prevent local government meddling in local financial intermediation; RCFs offer at least a semi-regulated environment for such activities. ${ }^{43}$ RCFs furthermore grant the type of small-volume, high-risk and high interest loans that the formal financial

43 The development of the RCFs so far is part of the increasing division of the financial sector according to ownership of the real economy. In the past decade provincial development banks and investment companies as well as municipal (urban commercial) banks were set up to support the respective tier's state-owned enterprises 
sector is unable to provide; their lending to rural enterprises and farmers is fully in line with the central government's desire to accelerate rural economic growth.

Are well-managed, local RCFs ushering in a monetary counterrevolution from the countryside? In contrast to the evolution of the household contracting system in agriculture in the early 1980s, RCFs are not privately run businesses changing the organizational landscape of financial intermediation in the countryside. However, RCFs constitute a counterrevolution from the countryside in that the times when the formal financial sector could easily siphon off cheap rural deposits into urban industrial and state-owned development have come to an end.

Furthermore, the development of sound RCFs puts pressure on the formal financial sector to make available loans to traditionally neglected borrower groups and on the $\mathrm{PBC}$ to further liberalize interest rates.

One response of the $\mathrm{PBC}$-apart from closing down some types of RCFs as illegal financial institutions - has been to require that RCFs offer deposit interest rates no higher than those of the formal financial sector; this is meant to stop the rapid growth of RCFs. But if the interest rate limit is not breached outright, dividend payments in addition to interest rates raise the de facto return on deposits (shares). If actual returns are market-driven, RCFs will simply continue to grow as long as those borrowers who do not have access to formal financial sector funds are willing to pay the higher $\mathrm{RCF}$ interest rates. The pressure for liberalization in the formal financial sector thus continues.

The attachment of RCFs to local governments and the RCF's government-influenced lending patterns are prima facie ironic given that the formal financial sector increasingly enjoys lending autonomy. The 
formal financial sector is abandoning the mandatory credit plan, while the RCFs perpetuate direct government interference in lending decisions. But the formal financial sector still lends in accordance with state policies and the-now indicative-credit plan. Liquidity problems are resolved through the $\mathrm{PBC}$ while the central government implicitly guarantees their solvency. Local governments and Party committees, on the other hand, have no recourse to $\mathrm{PBC}$ or central government should their RCFs fail. With local government budgets by far insufficient to bail out a RCF in severe trouble, lending decisions must take into account the economic viability of a project. The absence of a lender of last resort for RCFs thus is an incentive for sound banking.

Research by Sicular (1996) on agricultural procurement suggests that the distinction "state" vs. "non-state" agents is no longer meaningful and should be replaced by a distinction between officially designated procurement agents vs. other, non-designated commercial agents. In the case of rural finance, a similar argument runs to the effect that what matters are the degree of regulation and the prevalence of a hard budget constraint. RCFs can successfully fulfill their niche function and serve a clientele largely excluded from formal financial sector lending because of the absence of restrictive regulations of the type that apply in the formal financial sector, while the hard budget constraint of RCFs creates incentives for fundamentally market-oriented lending decisions.

But financial intermediation differs significantly from agricultural procurement in that individual household depositors have long-term stakes in the financial institution. The depositor thus would like to ascertain the RCF's financial health. RCFs then have a significant advantage over private sector competitors: where private sector financial

remain outside the central government's formal financial sector regulatory scope. 
institutions could face difficulty in gaining depositor trust in the early years of their existence, the attachment of RCFs to local government departments drastically lowers monitoring costs for individual depositors by providing an implicit deposit insurance guarantee. Although it may appear paradoxical given the usual belief in the need for wide-spread privatization during economic reform, government ownership or government management of RCFs could be superior to dispersed private sector solutions. 


\section{References}

AgMin. (Agricultural Ministry).

1994. "Nongyebu, zhongguo renminyinhang guanyu jiaqiang nongcun hezuo jijinhui guanli de tongzhi" (AgMin and PBC circular on strengthening the administration of the rural cooperative funds). Nongjingfa \#21/1994. In Jiang (1996), 165-8.

19 April 1995. "Guanyu kaizhan nongcun hezuo jijinhui dengji gongzuo de tongzhi" (Circular on starting registration of rural cooperative funds). In ZHRMGHGFLQS, pp. 1128-31.

CCPCC (Chinese Communist Party Central Committee).

19 Nov. 1991. "Guanyu jin yi bu jiaqiang nongye he nongcun gongzuo de jueding" (Decision on further strengthening agriculture and rural work). Eighth Plenum of the Thirteenth CCPCC. In Zhongguo gongchandang dangnei fagui zhidu shouce (19977), pp. 728-39.

1994. "Zhonggong zhongyang, guowuyuan guanyu 1994 nian nongye he nongcun gongzuo de yijian" (CCPCC and SC suggestions on agriculture and rural work in 1994). Zhongfa \#4/1994.

14 Oct. 1998. "Zhonggong zhongyang guanyu nongye he nongcun gongzuo ruogan zhongda wenti de jueding" (CCPCC decision on some very important issues of agriculture and rural work). Third Plenum of the Fifteenth CCPCC. In ZHRMGHGGWYGB, no. 26 (18 Nov. 1998): 9961011.

Chen Zhen and Liu Shucheng. "Mingque zhuguan bumen zhize, gaohao hezuo jijinhui guanli" (Clarify the responsibilities of the superordinate departments in order to manage the RCFs well). Nongcun hezuo jingji jingying guanli, no. 4 (April 1997): 22.

Dali xian. Dali xian RC.F administrative office and joint RCF. "Jianchi buxie de zhuahao guifanhua guanli" (Persevere in implementing standardization). Nongcun hezuo jingii jingying guanli, no. 7 (1997): 24f, 21.

Deng Anzhi. "Nongcun hezuo jijinhui de wenti yu duice" (Problems of RCFs and countermeasures). Nongcun jingji, no. 9 (Sept. 1998): $24 \mathrm{f}$.

"Dui nongcun hezuo jijinhui ying geiyu chongxin dingxing: henan sheng nongcun hezuo jijinhui de diaocha" (The character of the RCF should be newly determined: a survey of RCF in Henan Province). Jinrong yanjiu baogao \#12/1996 (11 April 1996).

Fan Yuming and Xu Yuanheng. "Guanyu qingli zhengdun he guifan nongcun jijinhui de sikao" (Thoughts on cleaning up, rectifying, and standardizing the rural cooperative funds). Shaanxi jinrong no. 9 (September 1997): 4-5

Fang Weilian. Xiangzhen qiye fa shiyong zhinan (Guide on the use of the township and village enterprise law). Beijing: Zhongguo nongye chubanshe, 1997. 
Guo Xiaoming and Yang Gang. "Nongcun hezuo jijinhui fazhan zhong de wenti yu duice" (Problems of RCF development and counter-policies). Nongcun jingji, no. 5 (May 1997): $1-4$.

Hebei Province Party Committee and Hebei Province Government. 6 July 1992 "Guanyu jin yi bu fazhan he banhao nongcun hezuo jijinhui de baogao" (Report on further developing and managing the rural cooperative funds).

Hu Biliang and Zhang Yuanhong. "Zhongguo nongcun jinrong bumen de gaige yu fazhan" (Reform and development of China's rural financial institutions). Academy of Social Sciences, Beijing. Manuscript, 1998.

Jiang Xuchao. Zhongguo minjian jinrong yanjiu (China's rural finance). Jinan: Shandong renmin chubanshe, 1996.

Jiang Youde and Wu Yadong. "Jiaqiang fengxian fangfan guanli de youxiao shouduan-Taixing shi nongcun hezuo jijinhui shixing zichan fuzhai bili guanli" (Effective measures to strengthen risk management--trial implementation of asset-liability ratios in the Taixing City RCFs). Nongcun hezuo jingji jingying guanli, no. 2 (Feb. 1997): $20 \mathrm{f}$.

NPC (National People's Congress).

18 March 1995. "Zhonghua renmin gongheguo zhongguo renmin yinhang fa" (People's Republic of China People's Bank of China Law). In Zuixin zhongyang yinhang shiwu quanshu, pp. 309-13.

10 May 1995. "Zhonghua renmin gongheguo gongshang yinhang fa" (People's Republic of China Commercial Bank Law). In Zuixin zhongyang yinhang shiwu quanshu, pp. 313-21.

29 Oct. 1996 "Zhonghua renmin gongheguo xiangzhen qiye fa" (PRC TVE Law). In Fang (1997), pp. 192-97.

Pang Zhongping, Zhang Zhengliang and Li Chengzhi. "Cujin jiankang fazhan, jianchi guifan guanli" (Accelerate the healthy development, adhere to standardized administration). Nongcun hezuo jingji jingying guanli, no. 5 (May 1997): 25f.

Park, Albert, Loren Brandt and John Giles. "Giving Credit Where Credit Is Due: The Changing Role of Rural Financial Institutions in China." Working Paper Nr. 71, The William Davidson Institute, March 1997.

PBC (People's Bank of China)

23 March 1998 "Fangfan he chuzhi jinrong jigou zhifu fengxian zanxing banfa" (Temporary measure on carefully handling the risk of bank runs at financial institutions). Yinfa \#49/1998. In Zhongguo renmin yinhang wengao no. 2 (1998): 3-9.

PBC Weinan Municipality. "Dui Weinan shi 1997 nian chuxu zengzhang qingkuang de diaocha (An investigation of the increase in household deposits in Weinan Municipality in 1997). Shaanxi jinrong, no. 3 (March 1998): $28 f$.

Qin Chijiang et al. Jinrong tizhi bianqian yu songjin zhuanhuan (Changes in the financial system and the switch from "lose" to "tight" monetary policy). Beijing: Zhongguo caizheng jingji chubanshe, 1993.

SC (State Council) 
17 Sept. 1988. "Jijinhui guanli banfa" (RCF administration measure). PRC SC decree \#18/1988. In Yinhang fa quanshu, p. $63 f$.

25 Dec. 1993. "Guanyu jinrong tizhi gaige de jueding" (Decision on reform of the financial system). Guofa \#91/1993. In ZHRMGHGGWYGB, no. 31 (1993): 1488-96.

22 Aug. 1996. "Guanyu nongcun jinrong tizhi gaige de jueding" (Decision on the reform of the rural financial system). Guofa \#33/1996. In ZHRMGHGGWYGB, no. 26 (1996): 1032-8.

13 July 1998 . "Feifa jinrong jigou he feifa jinrong yewu huodong qudi banfa" (Measures to eliminate illegal financial institutions and illegal financial business). SC. decree \#247/1998. Shaanxi zhengbao, no. 15 (15 Aug. 1998): 4-6.

11 Aug. 1998. "Guowuyuan bangongting zhuanfa zhongguo renmin yinhang zhengdun luan jizi luan pi jinrong jigou he luan ban jinrong yewu shishi fang'an de tongzhi" (SC office circular passing on the implementing scheme of the $\mathrm{PBC}$ on rectifying the disorderly raising of funds, the disorderly approval of financial institutions, and the disorderly conduct of financial business). Guobanfa \#126/1998. In ZHRMGHGGWYGB, no. 24 (22 Oct. 1998): 949-55.

Shaanxi Province TVE Administration Bureau (Shaanxi sheng xiangzhen qiye guanliju)

10 June 1997. "Guanyu wo sheng shiban xiangzhen qiye hezuo jijinhui qingkuang de baogao" (Report on the situation of the experimental TVE cooperative funds in Shaanxi Province).

29 November 1997. "Shaanxi sheng xiangzhen qiyeju guanche sheng zhengfu guanyu zhengdun jinrong zhixu youguan wenti de pifu de tongzhi (Shaanxi Province TVE Bureau circular on the reply by the provincial government regarding the rectification of certain problems in the financial order). Shaanxiang qijingfa \#179/1997.

ShGov (Shaanxi Province Government.

21 July 1997. "Shaanxi sheng renmin zhengfu pizhuan zhongguo renmin yinhang shaanxi sheng fenhang, shaanxi sheng nongyeting guanyu qingli zhengdun nongcun hezuo jijinhui de yijian de tongzhi" (Shaanxi Government circular approving the suggestions of the People's Bank of China Shaanxi Province branch and the Shaanxi Province Agricultural Bureau on cleaning up and rectifying rural cooperative funds). Shaanzhengfa \#31/1997. Shaanxi zhengbao, no. 15 (July 1997): 18-20.

9 Oct. 1998. "Shaanxi sheng renmin zhengfu bangongting guanyu renzhen kaizhan zhengdun jinrong 'san luan' gongzuo de tongzhi" (Shaanxi Province government office circular on sincerely starting off the work on rectifying the 'three disorderly' elements in the financial system). Shaanzheng banfa \#71/1998. Shaanxi zhengbao, no. 21 (15 Nov. 1998): $28 \mathrm{f}$.

Sicular, Terry. "Redefining State, Plan and Market: China's Reforms in Agricultural Commerce." In Andrew G. Walder (ed.), China's Transitional Economy. Oxford: Oxford University Press, 1996, pp. 58-84. 
State Tax Office (Guojia shuiwuju).

10 Feb. 1995 "Guanyu nongcun hezuo jijinhui suodeshui zhengguan wenti de tongzhi" (Circular on the income tax of rural cooperative funds). Guoshui hanfa \#58/1995. In Zhongguo shuishou zhidu, p. $576 \mathrm{f}$.

18 May 1995 "Guanyu qiye suodeshui zhengshou he guanli fanwei de tongzhi" (Circular on the the collection and administration of enterprise income taxes). Guoshuifa \#23/1995. In Zhongguo shuishou zhidu, p. $578 \mathrm{f}$.

SXNJ. Shaanxi nianjian (Shaanxi Yearbook). Xi'an: Shaanxi nianjian she, various years.

SXTJNJ. Shaanxi tongji nianjian (Shaanxi Province Statistical Yearbook). Beijing: Zhongguo tongji chubanshe, various years.

Tai Xiangdong. "Tuixing gufentian he nongcun hezuo jijinhui, jiasu nongye chanyehua jincheng" (Promoting the share-holding system for land holdings and promoting the RCF accelerates the progress of agricultural structural change). Shaanxi zhengbao, no. 1 (January 1998): 30.

Tsai, Kellee S. "Financing Private Enterprises in China: A Political Economic View from Below." Manuscript, Columbia University, 1999.

Wang Zheng and Yang Wenli. Shuịin jisuan yu kuaiji hesuan (Tax computation and accounting). Beijing: Zhongguo jingji chubanshe, 1997.

Wu Xiju. "Dui Weinan jinrong zhixu de jidian kanfa" (Some views on the financial order of Weinan." Shainxi jinrong, no. 9 (Sept. 1997): 6-7.

XATJNJ. Xi'an tongji nianjian (Xi'an Statistical Yearbook). Beijing: Zhongguo tongji chubanshe, various years.

Xi'anGov (Xi'an Municipality government).

27 April 1995 "Xi' an shi renmin zhengfu bangongting zhuanfa shi nongyeju guanyu jiji fazhan he banhao nongcun hezuo jijinhui de yijian de tongzhi" (Xi'an Municipality government office circular transmitting the suggestions of the municipal agricultural office on energetically developing and managing the rural cooperative funds). Shizheng banfa \#52/1995. In Xi'an zhengbao no. 5 (May 1995), pp. 33f.

Xiang Huaifang and Ceng Rongsheng. "Dui Gaoping qu nongcun hezuo jijinhui zijiin yingyun de diaocha fenxi' (An investigation and analysis of the use of funds by the RCFs in Gaoping District). Nongcun jingji, no. 5 (May 1998): $34 \mathrm{f}$.

$\mathrm{Xu} X \mathrm{Xia}$ bo and Deng Yingtao. Zhongguo nongcun jinrong de biange yu fazhan 1978-1990 (Transformation and development of China's rural finance 19781990). Hong Kong: Oxford University Press, 1994.

XZQYCWTJHZZL 1994. Xiangzhen qiye caiwu tongji huizong ziliao 1994 (TVE financial statistical material 1994). Agricultural Ministry, 1995.

Yang Longsheng. "Gaige renyuan guanli zhidu, baozheng jijinhui jiankang fazhan" (Reform the personnel administration system in order to guarantee the healthy development of the RCFs). Nongcun hezuo jingji jingying guanli, no. 2 (Feb. 1997): 19. 
Yang Zonglian. "Guanyu cujin nongcun hezuo jijinhui jiankang fazhan de jidian shexiang" (Some considerations on the healthy development of RCFs). Nongcun hezuo jingii jingying guanli, no. 1 (Jan. 1997): $31 \mathrm{f}$.

Yinhang fa quanshu (Collected banking laws). Beijing: Zhongguo shangye chubanshe, 1995.

Yu Jinguan. "Guifan nongcun hezuo jijinhui jingying keburonghuan" (To standardize the management of rural credit cooperatives requires immediate attention). Jinrong cankao, no. 4 (April 1997): 19-22.

Zhongguo gongchandang dangnei fagui zhidu shouce (Chinese Communist Party Party-internal laws and regulations handbook). Beijing: Hongqi chubanshe, 1997.

Zhongguo shuishou zhidu. (PRC Finance Ministry Tax Department) Beijing: Qiye guanli chubanshe, 1996.

Zhou Fangping. "Yi tai wu nong xing nong de 'zhutuiqi'" (A boost to agricultural self-help). Nongcun hezuo jingji jingying guanly, no. 7 (July 1997): $23 \mathrm{f}$.

ZGJRNJ. Zhongguo jinrong nianjian (China Finance Yearbook). Beijing: Zhongguo jinrong chubanshe, various years

ZGNCJRTJNJ. Zhongguo nongcun jinrong tongji nianjian (China Rural Finance Statistical Yearbook). Beijing: Zhongguo jinrong chubanshe, various years.

ZGTJNJ. Zhongguo tongii nianjian (China Statistical Yearbook). Beijing: Zhongguo tongji chubanshe, various years.

ZGXZQYNJ. Zhongguo xiangzhen qiye nianjian (China Township and Village Enterprise Yearbook). Beijing: Zhongguo nongye chubanshe, various years.

Zhongguo renmin yinhang Weinan shi fenhang ketizu (PBC Weinan Municipality branch study group). "Dui Weinan shi 1997 nian chuxu zengzhang qingkuang de diaocha" (Survey of the the savings deposit increases in Weinan Municipality in 1997). Shaanxi jinrong, no. 3 (March 1998): 28-29.

ZHRMGHGFLQS. Zhonghua renmin gongheguo falu quanshu (PRC Collected Laws). Changchun: Jilin renmin chubanshe. Various years.

ZHRMGHGGWYGB. Zhonghua renmin gongheguo guowuyuan gongbao (PRC SC Bulletin). Various years.

Zhu Delin and Hu Hai'ou. Zhongguo de huiheise jinrong: shichang fengyun yu lixing sikao (China's grey and black finance: fast-changing market and reasons for its evolution). Shanghai: Lixin kuaiji chubanshe, 1997.

Zuixin zhongyang yinhang shiw'u quanshu (Latest central bank almanac).

Beijing: Zhongguo jinrong chubanshe, 1995. 


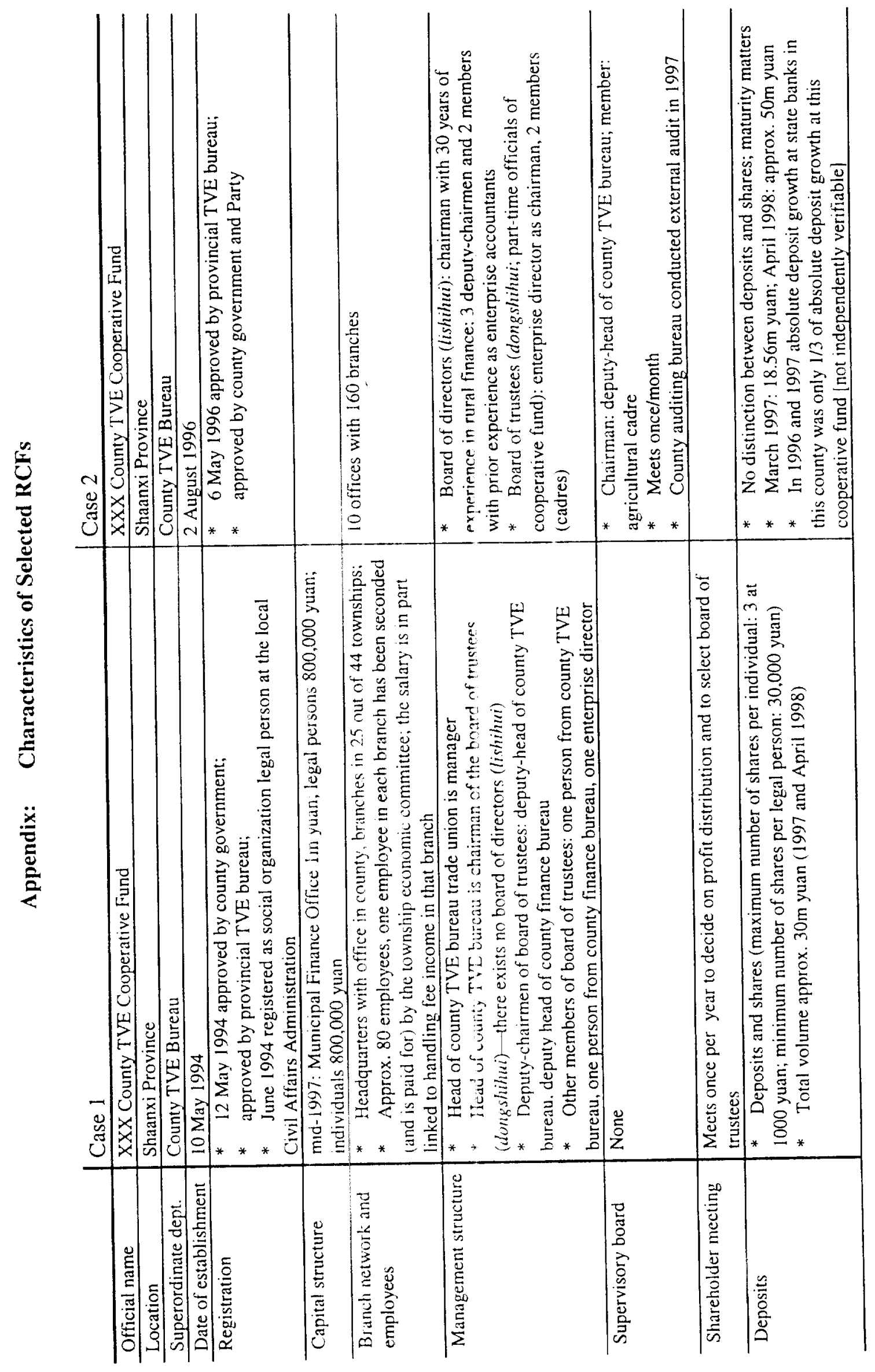




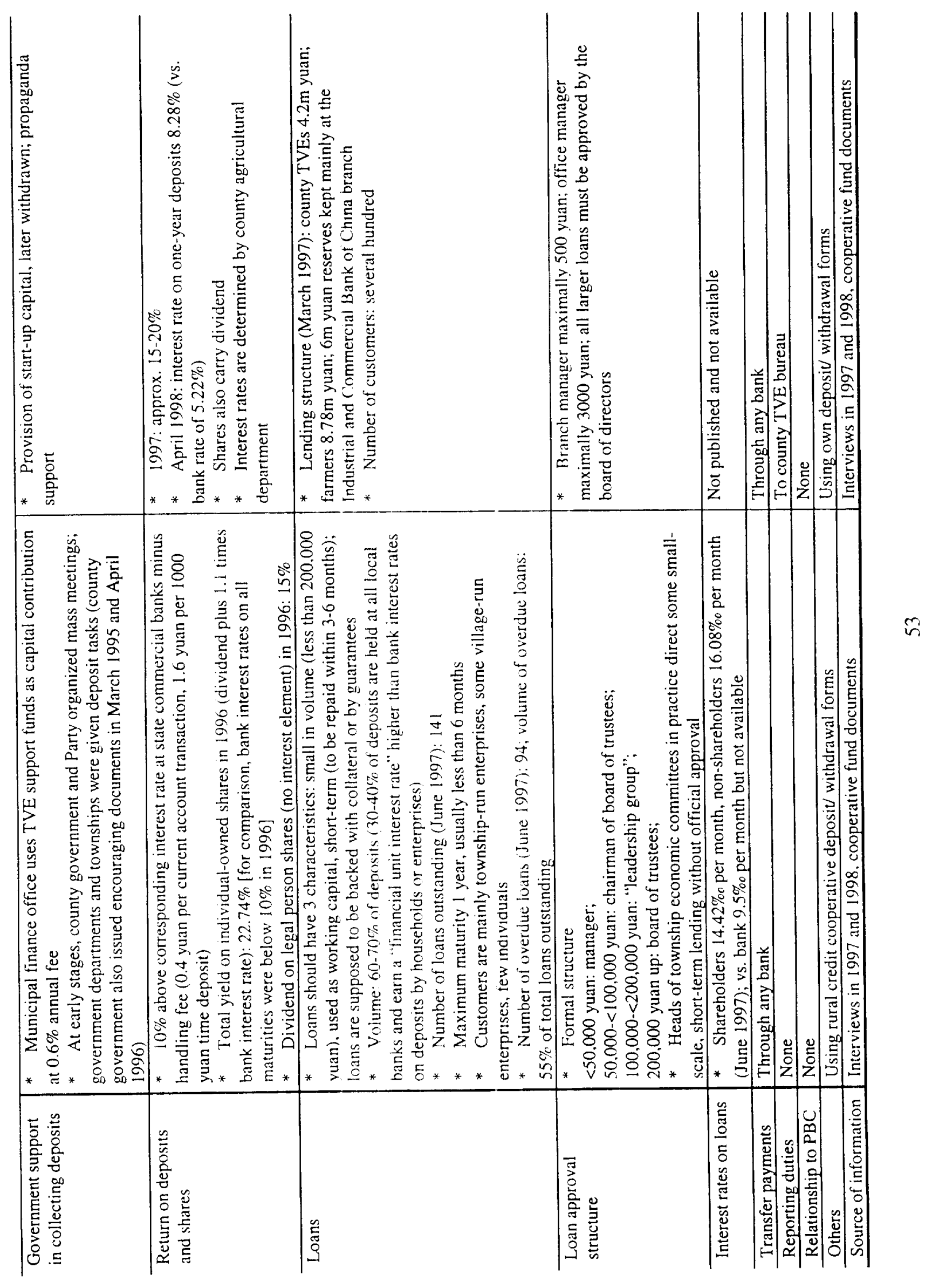




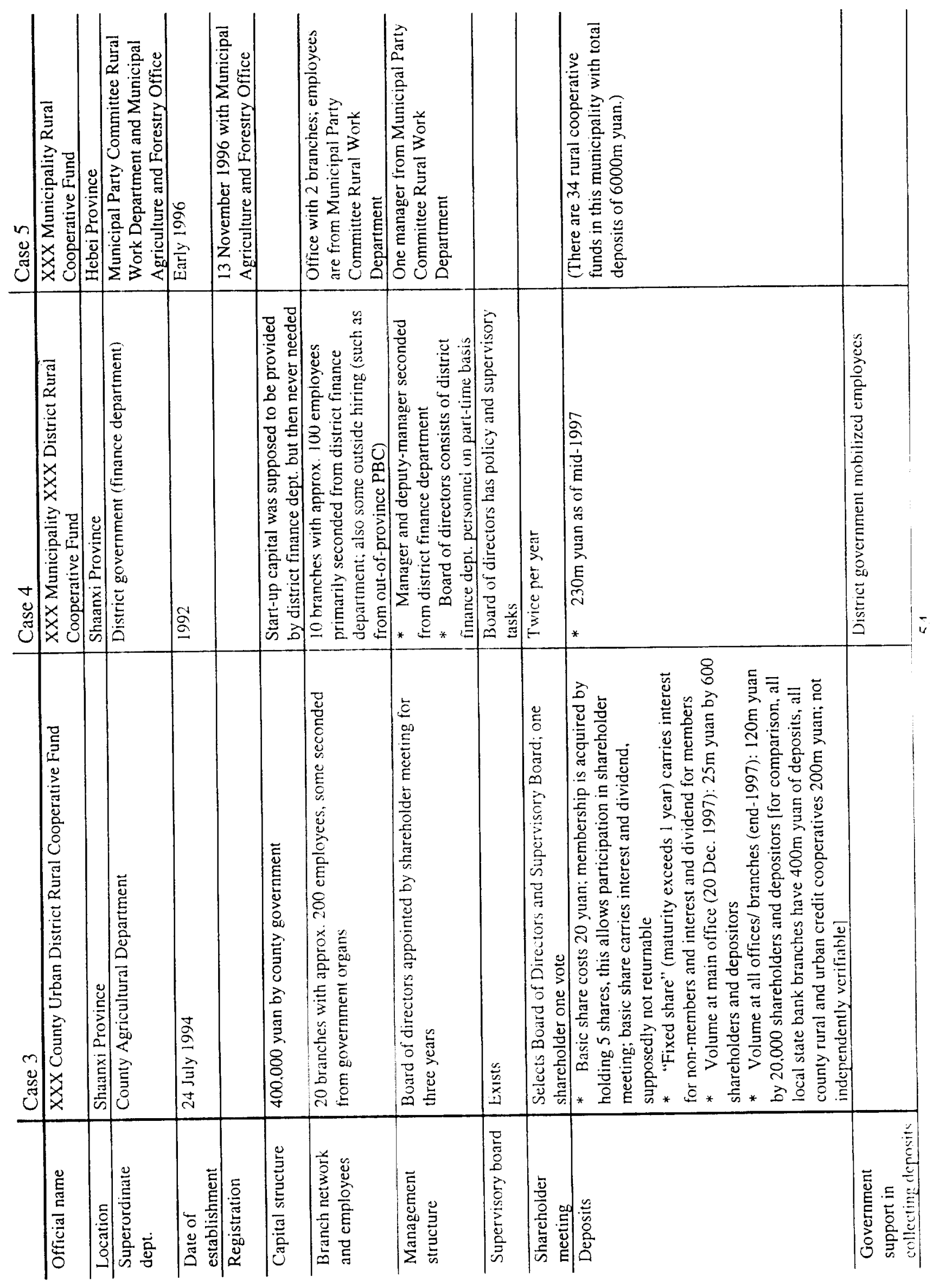




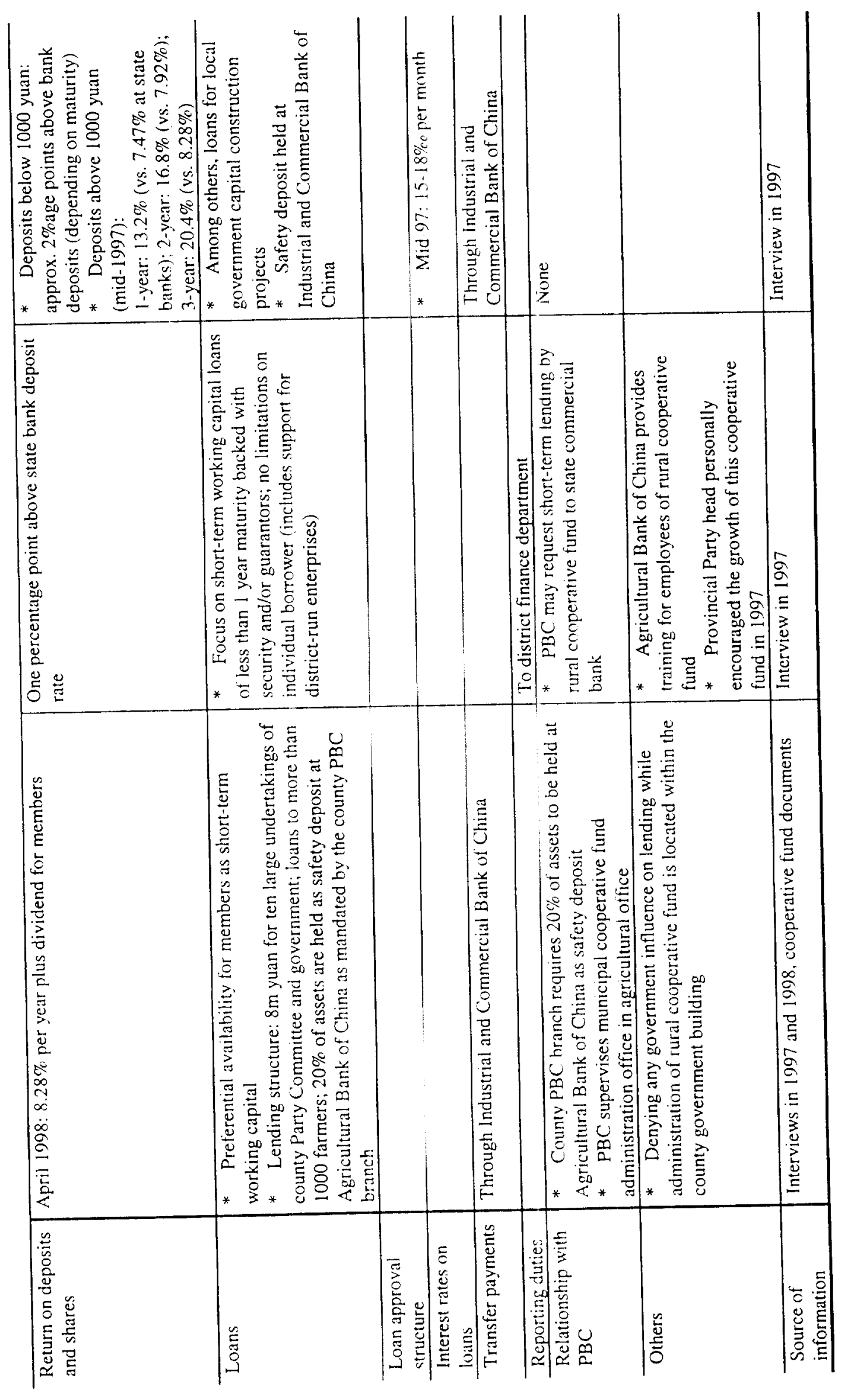




\section{Derivation of estimate of rural household deposits}

As the official "rural household deposits" are in effect nothing but household deposits at RCCs, urban (chengzhen or shizhen) vs. rural (nongcun) household deposits were constructed in the following way. First, annual increases in deposits ("depositing") by urban vs. rural households were constructed from urban as well rural survey data on household income and household expenditures. Second, 1990 total household deposits as given by official sources was split into urban vs. rural according to the relative size of urban vs. rural depositing in 1990. 1991 and later years' urban vs. rural household deposits were constructed by taking the previous years' deposits and attributing the official increase in total household deposits to urban vs. rural households in accordance with their current year depositing shares.

Since urban and rural surveys differ significantly in the items surveyed, the first step in turn required a number of calculations. In the case urban households, living expenditures (xictofeixing zhichu) were subtracted from income for living expenditures (shenghuofei shouru). Income for living expenditures is total income minus all kinds of taxes and various other items such as presents. It presumably is net of business expenditures by privately(and individual-) -run enterprises. In the case of rural households, annual expenditures were subtracted from total income. Annual expenditures include household business expenses, living expenditures, "other nonproductive expenditures" and an unspecified residual (which presumably includes taxes). Depositing thus derived is almost equal to depositing derived as net income (chun shouru), i.e.. income net of taxes and business expenditures but inclusive of all kinds of subsidies, minus living expenditures and other nonproductive expenditures. The first measure of depositing was then used. Depositing per capita thus derived for urban as well as for rural households was then multiplied by the number of persons living in urban vs. rural areas according to the population statistics.

Total depositing by all urban and rural citizens is equivalent to slightly below one half of the annual increase in official total household deposits across all years; reasons for the divergence may include inexact surveys, inexact construction of depositing here given the insufficient definitions of terms offered, and other factors such as borrowing by households-which is not included in any of the income items available-leading to deposits also outside the survey categories. As long as such flows occur in equal proportion relative to the income measures used here in both urban and rural areas they have no impact on the estimates used here. The approximations here are only constructed to obtain urban vs. rural depositing shares; these shares were then applied to official total household deposits (or increases thereof). Another complication is that urban areas include township-towns (zhen); the relevant rural share in the context here should thus be larger than estimated. 
Sources for household deposits: ZGJRNJ 1997, 467; ZGTJNJ 1998, 105, 326, 344; ZGTJNJ 1997, 293; ZGTJNJ 1996, 282; ZGTJNJ 1995, 262, 278; ZGTJNJ 1993, 286, 311. 